Modern Asian Studies 54, 4 (2020) pp. I225-127I. (C) Cambridge University Press 2019. This is an Open Access article, distributed under the terms of the Creative Commons Attribution licence (http://creativecommons.org/licenses/by/4.o/), which permits unrestricted re-use, distribution, and reproduction in any medium, provided the original work is properly cited.

doi:Io.IoI7/Soo26749XIgoooo39 First published online 3o October 2019

\title{
The Modernity of Caste and the Market Economy*
}

\author{
DAVID MOSSE
}

SOAS University of London

Email:1m21@soas.ac.uk

\begin{abstract}
What place does the caste system have in modern India with its globally integrating market economy? The most influential anthropological approaches to caste have tended to emphasize caste as India's traditional religious and ritual order, or (treating such order as a product of the colonial encounter) as shaped politically, especially today by the dynamics of caste-based electoral politics. Less attention has been paid to caste effects in the economy. This article argues that the scholarly framing of caste mirrors a public-policy 'enclosure' of caste in the non-modern realm of religion and 'caste politics', while aligning modernity to the caste-erasing market economy. Village-level fieldwork in South India finds a parallel public narrative of caste either as ritual rank eroded by market relations or as identity politics deflected from everyday economic life. But, locally and nationally, the effects of caste are found to be pervasive in labour markets and the business economy. In the age of the market, caste is a resource, sometimes in the form of a network, its opportunityhoarding advantages discriminating against others. Dalits are not discriminated by caste as a set of relations separate from economy, but by the very economic and market processes through which they often seek liberation. The caste processes, enclosures, and evasions in post-liberalization India suggest the need to rethink the modernity of caste beyond orientalist and post-colonial frameworks, and consider the
\end{abstract}

* Versions of this article were delivered as the OP Jindal Distinguished Lecture at the Watson Institute, Brown University on I November 2017, and as the Munro Lecture, University of Edinburgh on 22 March 2018. I am grateful to the organizers of these public lectures (especially Bhrigupati Singh and Ian Harper), discussants, and audiences. For comments on an earlier draft (including useful references), thanks are also due to Sara Besky, Buswala Bhawani, Shruti Kapila, Anirudh Krishna, Nate Roberts, Ed Simpson, Annapurna Waughray, and the anonymous reviewers. This research was supported by a UK Economic and Social Research Council (ESRC) grant, 'Caste Out of Development', ES/Hoogo5I/r. The usual disclaimers apply. 
presuppositions that shape understanding of an institution, the nature and experience of which are determined by the inequalities and subject positions it produces.

\section{Introduction}

What do we learn about the Indian caste system if we begin not with 'traditional' Hindu religious ideas or contemporary political competition, but with relations of the modern economy - a domain in which caste identity and hierarchy are often understood to be absent or eroded by market processes? In this article, I want to draw attention to a growing body of research that has precisely this focus and consider the implications of this evidence for how we conceptualize caste as a contemporary phenomenon in Indian society and economy. This is especially important because of contention surrounding the social transformation attributed to India's rapid economic growth and the significance of caste in shaping new opportunity or new inequality. But, before turning to the recent evidence on caste and the market economy (in the second part of this article), I have another question, namely why has this dimension of caste received so little attention, or maybe active inattention?

A few years ago, I began a collaborative project entitled 'Caste Out of Development'. 'Apart from the obvious reference to a kind of social exclusion, this signalled what I had observed as the discursive exclusion of caste from policy framing in international development. I became interested in how a phenomenon so ubiquitous an aspect of socio-economic and political life could disappear from view within certain discursive fields, in this case development policy. Why is caste, which, for a large section of humanity, is at least as pervasive as gender, race, age, religion, or other dimensions of human inequality and discrimination, absent from global policy debate and its intergovernmental platforms such as the Sustainable Development Goals?

The purpose of the first part of this article is to understand what bounds the discursive space for public debate on caste, especially in relation to the market economy. I should be clear that, here, 'caste' is not a transhistorical social category, but refers to any of a wide variety of phenomena including the identity of endogamous groups (jatis) or clusters of them, a division of labour, a social classification, the attribution of inherent or cultural

\footnotetext{
${ }^{1}$ http://www.researchcatalogue.esrc.ac.uk/grants/RES-o62-23-2227/read (accessed 24 September 2019).
} 
difference, a public representation of social rank, a network, a set of values, social judgements or discriminations (of people, spaces, markets, practices), an administrative or legal category, among others. Caste is an effect, perhaps of inequality, exclusion, discrimination, or opportunity hoarding, and especially produces a social cleavage between Dalits (the 'former untouchables') and others. Polyvalent 'caste' moreover exists only in relation to, or as an aspect of, other social relations or transactions such as of gender, class, employment, markets, electoral politics (and so on), made salient in specific contexts that might be characterized as rural or urban, industrial, commercial or institutional (of education, law, religion), or in discourses of policy or politics. Modern caste is not one thing, but neither is it anything. It is a clustered set of social phenomena and effects, recognized and spoken of as 'caste', brought to attention or concealed. My focus is on when and in what form caste is made visible or invisible.

What I will suggest is that investment in a contemporary arrangement of categories (with its own history) that distinguishes religion, politics and market economy, or tradition and modernity serves to organize attention and inattention to caste processes in public narratives, and, in particular, that the modern market economy is a field in which the pervasive effects of caste are rendered invisible in ways that may serve selected interests by concealing processes of advantage and discrimination. The narratives of caste and economy that I will draw attention to relate to knowledge present or institutionalized in different fields: in scholarship, in social policy, and in Indian village life, which I take in turn.

\section{Invisibilizing caste economics: the enclosure of caste in religion and politics}

\section{Caste in scholarship: religion, politics, and economy}

The question of what makes caste appear or disappear from view is not new. Indeed, a considerable part of anthropological scholarship on caste over the past half-century has been given over precisely to debating the conditions of knowledge about caste. In his ambitious book, Homo Hierarchicus, Louis Dumont (I980) insisted that the reality of caste could only be known at the ideological level, the empirical multitude of in-marrying groups, or jatis, acquiring coherence in terms of the complementary hierarchy of 'the pure' and 'the impure' that, as a pre-eminent value, 'encompassed' matters of power and politics, just as 
Brahman priesthood hierarchically encompassed Kshatriya rulership in the ancient varna classification. The reality of caste was not to be grasped in the realm of politics or economics.

Critics of this ontological rendering of caste folded into Brahmanic ideology were no less insistent that caste came into reality as an ideological effect reordering a complex empirical reality, but this timeas Nicholas Dirks sets out in his book, Castes of Mind (200I) — an effect of the British colonial system of knowledge that produced caste as India's 'traditional' religious and ritual order. Dirks maintained that caste became the quintessential colonial idea of Indian civil society through the imposition of an orientalist idea onto diverse forms of identity and community, masking the true 'political struggle and processes' of caste as a product of the colonial encounter (Dirks 200I, II).

While nationalist notions of Indian civilization continued to locate caste in the Hindu religious system, with its archetypal victims (the polluted 'untouchables') subject to Gandhian reform or social mobility construed as ritual emulation or 'Sanskritization' (Rawat and Satyanarayana 20I6, Io), a post-colonial sensibility has drawn caste (in its public form) primarily into a framework of 'politics', reaching its 'apotheosis' (Dirks 200I, 6) with debates over the state's affirmative-action 'quotas', and the dynamics of caste-based electoral politics. Secularized and horizontalized by liberal democracy, caste reappears no longer as a system, but with a new core characteristic as competing ethnic-like or cultural identities (Gupta 2005), entrenched and reproduced by electoral dynamics or caste-based 'quotas', sometimes criticized as a colonial legacy (Rawat and Satyanarayana 2016, I3).

If I want to claim that caste, first enclosed within 'religion', is now enclosed within 'politics', it is only possible to do so with reference to a third category: the 'economic'. Dumont's use of religion (that is Hindu ideology) was challenged because it was seen as a category of analysis of Indian society produced by colonial claims about the Western modernity of the public domain of politics that rendered caste as Hindu religious tradition, denying its politics. What I am suggesting here is that an enclosure of caste within politics is, in parallel, an effect of contemporary (neo-liberal) claims to the modernity of the market economy, which renders caste a matter of politics by denying caste economics. Unlike Brahmanic or Orientalist ideological effects that make caste visible, economic knowledge (and derivatively development discourse) makes caste phenomena disappear through discursive exclusion.

The question of how this might be so takes us back to Dumont, not to his oft-challenged separation of the religious from the political, but to his 
separation of the sphere of the 'economic modern' (in India no less regarded a product of colonial rule) as the categorical opposite of caste society. Dumont insists that, from a caste-system viewpoint, economics as a separate category (and value) does not exist, since resource rights are only complementary parts of an ordered whole that is religious (I980, I64-66). In his later work, Dumont (1977) develops the implication, namely that peculiarly modern economic values (with individual property rights, land and labour as marketable commodities, and so on) are incompatible with a holistic system such as caste. ${ }^{2}$

Dumont (1977) is far from alone in paying attention to the conditions of existence of 'economy' as a peculiar social, ethical, and discursive domain. He follows Karl Polanyi (1957) in seeing the thought/value of 'economics' rising in late seventeenth- and eighteenth-century Europe, when relations between people and things (wealth and property) were no longer subordinated to relations between people (the political) and when exchange was newly viewed as volitional and mutually advantageous, leading to the conception of an economic system with laws and morality of its own - 'a self-contained sphere, distinct from the social, the cultural, and other spheres' (Mitchell I998, 9I). Others, such as Kalpagam, find in British colonial India - its systems of private property, practices of measurement and standardization, accounting and statistical analysis (and so on) - both the administration of an economy and maintenance of 'a discourse of "the economy" (Kalpagam 2000, 430).

Birla (20II; 2008) takes two further significant steps, first showing how, from the late nineteenth century, the British introduced a legal infrastructure that institutionalized 'the market', disembedded from earlier social arrangements and now standing in for 'the public' and comprised of colonial subjects governed (and 'civilized') as economic agents and consumers (namely by principles, rules, and relations of contract). Second, Birla argues that this 'market governance' and its modern abstraction, 'the economy', required that the excluded socialities of economic life - the negotiable codes of kinship, caste, trust, or honour of 'vernacular capitalism' - were recoded as 'culture', as the 'private' to the market's 'public', stabilized under scripted logics of religious-personal law and preserved as custom through the post-I859 colonial policy of

\footnotetext{
${ }^{2}$ Dumont's argument (at the level of values) is that, in modern individualist society, there is no logical alternative to the ideology of market economics. Only under totalitarianism, he insists, would the autonomy of the economic be displaced, and social subordination and hierarchy be reproduced within the market economy (Dumont I977, I07; Rosen 1978, 213).
} 
'non-interference' (Birla 2011, I023-25). In short, colonial liberalism that abstracted or disembedded 'the economy' rewrote 'the social' as the market and, in doing so, placed relations of caste (and kinship) in a non-market-protected domain of religion and culture, institutionalizing a disjucture between the spheres of the economic-public and the cultural-private (Birla 20II, IO3I). As Birla (invoking Dumont) puts it, 'colonial law grappled with the embeddedness of vernacular capitalism by casting Homo aequalis (economic man) as the public actor and Homo hierarchicus, his private cultural counterpart, as his effect' (Birla 20I0, 94).

The idea of a distinct, or antecedent, pre-colonial Indian caste society separate from monetized market economy is of course demonstrably false (see Fuller i989) and the argument that Indian villages (the classic locus of caste tradition) have for centuries been integrated into this economy through trade and commerce no longer needs to be made. But the dichotomy of caste tradition and market modernity that made those arguments necessary (outliving the separation of non-monetary and monetary exchange) persists in the idea that, ultimately, it is the modern market economy that will ensure that caste itself is but an incompatible fading residuum. Indeed, even Marxist historians such as Irfan Habib, who supply much of the evidence against Dumont's premise (Habib I982 in Fuller 1989) and conceive the history of caste in terms of its economic base, conclude that the modern economy (industrial development or the commercialization of agriculture) has so shaken the traditional hereditary division of labour that caste survives only in its religious and personal aspects that Dumont is criticized for privileging (Habib 2002, I64, I78). And F. G. Bailey (1957), who was among those anthropologists who regarded caste as a system of village political and economic organization, saw access to new commercial activity beyond land, and the introduction of the state administration, as eroding the politico-economic function of caste. Caste was a necessarily localized structure, engaged with a new 'economic frontier' (in Bailey's I950s rural India). Caste either 'canalized' forces of economic change into its own system or, by trying to inhibit these forces, destroyed itself (Bailey I957, 269-7I). To adapt Hirschman's (ig82) triad of rival interpretations of market society in Europe (from the eighteenth century), it could further be said: that the market and its demand for respectful mutual utility civilizes caste as an archaic system of honour and prejudice; or that the individual self-interest of market capitalism corrodes caste as traditional moral value; or that caste persists as a pre-capitalist remnant obstructing capitalist development. Always in opposition, caste is never integral to modern market economy. 
A more recent focus has been on the effect of the economy, or economics, as a discourse (and this in part is Dumont's point) in relation to caste, and this takes two forms. On the one hand, economics (and 'the market') is an ideology or a representation abstracted from actual socio-cultural relationships (including those in markets) as the 'virtual' world of economists (Miller 2002) misconstruing the actual social (and caste) embeddedness of economic relations. On the other, economics is performative, its models effecting self-fulfilling re-arrangements, dissociations, or the social 'disentanglement' of agents necessary for markets to exist - that is, for the alienation, possession, and exchange of commodities or services (Callon I998; MacKenzie, Muniesa, and Siu 2007; Slater 2002). In this sense, '[t] he economy', as Timothy Mitchell argues, is a representation (perhaps of mechanical flows) that is made true through a new field of practices of planning, regulation, or development management (Mitchell I998), while economics itself is a science that 'helps make of the wider world places where its facts can survive' (Mitchell 2008, inig).

These two perspectives entail each other. The 'framing' Callon refers to as necessary for market exchange is not a given, but requires work, investment, and a kind of 'staging' of social 'disentanglements' that are contingent, unstable, that cross agent networks and are separated from life outside the market by boundaries that are negotiable (Slater 2002). Moreover, actual markets work only through specific cultural entanglements and social categorizations, including those of caste (see below) (Slater 2002, 247; Miller 2002). A market framing of actors and their relationships is thus not disembedded from caste relations, but in fact becomes part of the renegotiation of caste (both erased and reasserted). But, as a representational domain, the market economy involves a constitutive exclusion of closely aligned relations of caste, gender, and family, as part of the 'non-economic' upon which, of course, the economic nonetheless depends to reproduce labour or access to markets (Mitchell I998, 99). Caste characterized by this 'exclusion-yet-dependence' (Mitchell 1998, 99) is both changed and disguised in a pervasive market-economy common sense. Caste has indeed become tradition in relation to the modern economy, or the pre-capitalist in relation to the capitalist, culture in relation to economy, private to public, or as that into which economic relations are 'socially embedded' (as Granovetter (1985) and others suggest), an idea which, Mitchell (2008) points out, presumes an actual realm of pure economic actors and processes with social identity/location-less buyer-seller exchanges, when what is really at issue is the social structuring, indeed 
the caste structuring, of the economy itself (a point returned to at the end of the article, drawing on the analysis of Pierre Bourdieu).

Arguably, then, the working of caste in the modern market economy has not attracted the attention that caste in politics has (the exceptions are discussed below) because of the more general way in which the economic sphere is produced (through a dispersed set of discourses, practices, and subjectivities (Slater 2002)). But the specific occlusion occurs because the public common-sense relegation of caste to politics (or religion) and alignment of 'the modern' to the market economy is itself an ideology of modern caste.

In a brilliant article, 'One Step Outside Modernity', on caste and the public sphere, the late M. S. S. Pandian drew attention to the sharply divided contemporary discourse on caste - an upper-caste silence on caste is counterpoised to the politics of difference in lower-caste struggles. He points to how the language of caste is delegitimized in the modern public domain, annexed as the religious/cultural 'inner' domain of the non-modern, and, by extension, how 'caste politics' is the non-modern to the market economy; but he goes on to say that the 'Indian modern, despite its claim to be universal-and of course, because of it - not only constitutes lower castes as its "other", but also inscribes itself silently as upper caste. Thus, caste, as the other of the modern, always belongs to the lower castes' (Pandian 2002, I738).

Regarding the inattention to caste in economy, what concerns me here, then, is the cultural logic within which markets and economics are located, bounded-off, deployed politically (or as a moral discourse) in the reproduction, refusal, or renegotiation of caste (in nation and village)economics, that is, as a 'category of practice' (Curtis and Spencer 2012, I79). The challenge here of sustaining attention to caste in modernity especially in the market economy, in the universal discourses of planning, economics, or human rights, focused on unequal relations (rather than religion and culture, or even politics) - a challenge inaugurated most obviously by Dalit leader Dr B. R. Ambedkar-is of course also the refusal to align the experience of discrimination to the condition of underdevelopment or to permit caste itself to be taken as 'a subaltern formation' (Subramanian 2015, 296). Implicitly, there is also here a claim against caste from the morality of the market - that it should be caste-free.

The scholarly and political shift here was inaugurated by the activism of inferiorized caste groups such as Dalits in the I99os, coinciding with the liberalization of the Indian economy, and the struggles for dignity born of social experiences of continuing discrimination and humiliation in the age 
of the market (Rawat and Satyanarayana 2016, 2-4). Dalit intellectuals posed a challenge to prevailing categories and distinctions. They refused to see colonialism as a unified discourse of power or as the decisive historical break (retrieving from the nationalist narrative a history of Dalit protests, partly enabled by colonial institutions and configurations of power, Rawat and Satyanarayana 2016, Iо) and they reinterpreted propositions about 'caste' being a cultural mode of oppression of the colonized by the colonizer as actually a means to allow 'a postcolonial elite to masquerade as the oppressed rather than the oppressors' (Dirks 200I, 312). ${ }^{3}$ Taking inspiration from the work of Bhimrao Ambedkar on the pervasiveness of caste effects, Dalit scholars rejected the submersion of caste into the analysis of class as much as into colonialism and the post-colonial elite claim to modernity that invisibilized ascriptive caste in society and economy.

Most important here, Dalit studies have fostered a body of research, ${ }^{4}$ chiefly by economists, focused on the caste-regulated and caste-networked nature of the Indian market economy, discarding categorical separations of religion, politics, or economy, while indicating the need for a new model of modern caste.

Before turning to this evidence, I have two further perspectives on the public discourses that organize attention away from 'caste economics'. The first concerns Indian social policy and the way in which it has separated caste from the realm of the modern economy and (as mentioned) excluded caste from policy on development. The second comes from village life, where my fieldwork finds a parallel separating-out of caste as ritual rank eroded by market relations, on the one hand, and identity politics, on the other, in ways that hide the growing importance of caste in shaping new economic opportunity.

\section{Caste in social policy: socio-religious disability and political empowerment}

\section{Policy enclosure of caste in religion and culture}

In post-independent India, there was a marked reluctance to use caste to explain poverty and inequality. As Christophe Jaffrelot points out, the

\footnotetext{
${ }^{3}$ These are the terms in which Dirks describes the Cambridge-school historians' critique of post-Orientalist attention focused on the colonial and caste, as against capital and class.

${ }^{4}$ Including through the Indian Institute for Dalit Studies formed in 2003, http:// dalitstudies.org.in (accessed 24 September 2019).
} 
'resolutely modernist attitude that permeated' planning in Jawaharlal Nehru's government combined a rejection of colonial caste-based classifications threatening the unity of the new nation, Marxist class universalism, and Gandhian utopianism, and anticipated that 'social and other distinctions will disappear' with the development advance towards 'the establishment of a society on the socialist pattern', as Home Minister G. B. Pant put it in rejecting the use of caste in a 1953 commission on the 'Backward Classes' (Jaffrelot 2006, I78-79). Caste was an archaic institution weakened by modern market forces that were as incompatible with caste's continuity as Marx considered the colonial railways to be (Dumont I980, 216). Moreover, as Uday Mehta (2010) argues, the constitutionally defined domain of policy, politics, and the state supplanted the social order as a locus of authority, official power being legitimized in projects of national unity and the uplifting of socially unmarked individual citizens that gave no recognition to existing caste identity and relations. ${ }^{5}$

The exception to the nationalist-secular exclusion of caste concerned the former 'untouchables' (today's Dalits). Indeed, caste entered modern public-policy debate through provisions for those whose 'backwardness' was seen as arising from historical Hindu practices of 'untouchability'a notion still without definition or test (Galanter I984; Dirks 200I)now compensated by provisions of the Constitution, and the protections afforded to them as Scheduled Castes. This is a category defined in religious terms so as to exclude Dalits of Muslim or Christian affiliation.

In treating Dalits as essentially religious subjects, and enclaving caste as a matter of religion, separate from political economy, the Indian state inherited categorizations that (as well as being an effect of the above-mentioned 'market governance') Rupa Viswanath finds rooted in Protestant missionary engagement with Dalits in the late nineteenth century. Her recent book, The Pariah Problem (2014b) describes a chain of events and reactions that led a Dalit ... of Dalit labour. Later, M. K. Gandhi would insist on Hindu reform and penitence - change withinas the route to the emancipation of the untouchables, the British governing principle of religious non-interference having already closed off caste practices from state intervention.

\footnotetext{
${ }^{5}$ As Shruti Kapila (2015) points out, Ambedkar on the contrary 'took the division and antagonism of the social, namely caste, as primary, and as one that required recognition within the realm of the political', warning against the dominant nationalist (Congress) 'ignoring of the social question in its pure pursuit of the political'.
} 
When Dalits did eventually gain citizen rights to formerly barred public spaces such as temples or water sources (by which time untouchability had been secularized as civic exclusion, through colonial ideas of public access (Rao 2009, 82, I30)), and when Dalit representatives in the twentieth-century system of devolved governance such as the Madras Legislative Council, raised objection to continued caste exclusion, Viswanath argues, the government treated this as a matter of 'the social realm'. This was something regarded as self-regulating and properly subject to gradual reform from within (of the kind Gandhi advocated) rather than as the infringement of socio-political rights, requiring legal/ state intervention (as Ambedkar proposed) (Viswanath 2014b, 222 et seq.).

The point I take from this is that missionary and colonial policy, which disembedded ritual caste from political economy and separated 'the social' from the properly governmental (culture from economy, private from public), put in place the modern structure of categories that still works to remove caste from the realm of mainstream development policy. This was earlier seen in the way the colonial Labour Department and labour policy were separated from policy on the Depressed Classes (the Dalits) (Viswanath 20I4a; 20I4b, 224) and today in the way social policy construes caste (as it affects the condition of Dalits) not as a matter of political economy, but as a specific 'social disability'. Caste is addressed as a (static) residual problem dealt with through remedial protections, safeguards, and complaint handling for marginal groups, so that they may, in the rubric, overcome their social and educational handicaps and 'catch up with the rest of the population' (NCSG 2016, I6). ${ }^{6}$ In state policy, caste is not a (dynamic) relational problem, critical to the ongoing unequalizing socio-economic processes within the 'rest of the population', as Ambedkar had insisted, ${ }^{7}$ even though the key Ministry

\footnotetext{
${ }^{6}$ See http://socialjustice.nic.in/UserView/index?mid=I5IO (accessed 24 September 2019). The Ministry of Social Justice and Empowerment is the nodal Ministry overseeing the interests of the Scheduled Castes and the legal protections and schemes of assistance via the state Scheduled Castes Development Corporations (SCDCs) (Berg 20I4, 245). The National Commission for Scheduled Castes (separately constituted) advises on constitutional safeguards (on matters of untouchability, forced and child labour, and temple entry) and 'special provisions' (affirmative action). Its 2016 Handbook does not use the word 'caste' as a noun (aside from the named Scheduled Castes), except once in connection with untouchability (NCSC 2016, 87).

${ }^{7}$ Ambedkar (1947, 409-10) maintained that the economy was rooted in structures of caste and warned against the separation of Fundamental Rights from economic rights, political freedoms from preconditioning economic freedoms, and political democracy from economic democracy (see insightful discussion in Rupa Viswanath's 2018
} 
and Commission responsible derive their mandate from the Indian Constitution's Fundamental Rights on equality. ${ }^{8}$

In other words, while socially disabled groups are subjects of policy and interventions, caste as a socio-economic process is not. Everyday caste is a matter of culture and society, not of government; it lies 'behind the veil' of law. ${ }^{9}$ Or, put another way, the conditions of Dalits are addressed as claims or demands on the government for services, education, or proportional development budgets (and so on), framed in terms of 'special measures' (affirmative action) rather than in terms of the state's general duty to address caste as discrimination and structural inequality in economy and society (Waughray 2010, 336- 37 ). ${ }^{10}$ While this 'affirmative action' seeks to alleviate disadvantage it does not aim to address its cause (Castellino 2017, 238-39), that is prejudice in society and its politicaleconomic underpinning for which there is no legal redress through civil anti-discrimination or equality legislation. ${ }^{11}$ In policy terms, everyday relations of caste are a matter for social and increasingly now neo-liberal market self-transformation. ${ }^{12}$ They only come into the view of the law when exceptionalized in the criminal juridical category of 'caste atrocities' - that is, specified wrongs with individual perpetrators (Rao 2009, 242). The special protections and schedules, meanwhile, fix Dalit identity in relation to lineage and historical-religious injustice rather than present aspiration, while precluding transformation of that burdened identity, for example by religious conversion (to Islam or Christianity), which would sacrifice legal protections and welfare entitlements (Krishnan 2012).

Ambedkar Lecture, 27 April 2018, Centre for South Asian Studies, University of Edinburgh, https://routesblog.com/2018/o4/28/fifth-annual-dr-b-r-ambedkar-lecture-atthe-university-of-edinburgh/ (accessed 24 September 2019)).

${ }^{8}$ On the distinction between residual and relational approaches, see Mosse (2010).

${ }^{9}$ Annapurna Waughray, personal communication.

${ }^{10}$ Take the example suggested by Rajan Kurai Krishnan: suppose Dalits are excluded from a water source installed by the state in the main village (the Tamil $\bar{u}$ ); the conflict that arises is resolved by the provision of another water facility in the Dalit colony (the cérn). What is absent is any challenge to the power, labour control, and denial of property that divides villages into the dominant $\bar{u}$ and the Dalit céri in the first place (personal communication).

${ }^{11}$ India has no civil anti-discrimination or equality legislation, although this has recently been proposed in the form of an Anti-Discrimination and Equality Bill, introduced in the Lok Sabha (the lower house) in March 2017 by Congress MP Sashi Tharoor.

${ }^{12}$ Whereas, under India's international human rights law commitments, they should also be matter of legal obligation (Annapurna Waughray, personal communication). 
The significance of caste in unequal economic processes is thus lost in the 'culturalization' of caste (Natrajan 20II) and, when construed as an issue of Indian religion and culture, caste is no matter for global policy and international agencies, whose concern with poverty or social exclusion is anyway overwritten in the 'new development relationship' with India, focused on trade and private-sector business. When talking with Indian or expatriate staff at the World Bank, United Nations, or aid agencies in Delhi in 20II-I2, I was indeed struck by the marked nervousness surrounding the issue of caste. Among bureaucrats and non-governmental organization (NGO) workers, the degree of openness to the topic was often a reflection of the caste identity of my interlocutors. The underlying message is that caste is an internal matter, unique both in form and in solution to India as a post-colonial nation, and the Indian government has ensured that it does not have monitored accountability to UN treaty bodies for its record on caste inequality or discrimination as a matter of human rights (see Mosse 2020).

If caste eludes mainstream development policy/planning, because, as argued, it is first enclosed within religion, culture and 'the social', caste has more recently been enclosed within politics. This is the second policy framing to which I now turn.

\section{Policy enclosure of caste within politics}

The second (1980) Commission on the Socially Backward Classes (or Mandal Commission) introduced the hitherto politically and judicially rejected idea that caste could be used as a criterion of socio-economic backwardness (rather than socio-ritual disability) and extended quota reservations (for example, for government jobs) to a diverse collection of so-called Other Backward Classes (the OBCs), some 3,743 caste identities comprising 52 per cent of the population. As the Mandal Report put it, 'caste is also a class of citizen' (cited in Jaffrelot 2006, I83) and socio-economic backwardness a caste-collective (or categorical) effect (Jayal 2015, I22). But, as Jaffrelot argues, the rationale behind the eventual implementation of Mandal's recommendations was not so much to view caste in relation to economic processes and improve the position of caste-disadvantaged groups as to empower them politically (Jaffrelot 2006, 183). 'We believe,' said Prime Minister V. P. Singh announcing the schemes in I990, 'that no section can be uplifted merely by money. They can develop only if they have a share in power ... [and in the] running of the country' (in Jaffrelot 2006, I83).

The upper-caste violent protest against extending reservations that ensued certainly brought political substance to what began as an 
abstract administrative category - the OBCs - and later electoral success to their caste-based parties - a political rise of 'lower'"13 castes that Jaffrelot calls the 'silent revolution'. This brought a 'new legitimacy to caste in the public sphere' (Jaffrelot 2006, I85), belatedly fulfilling Ambedkar's intention that caste, which had been perpetuated as a hidden violence in the concealed domain of the social, should (through provisions of affirmative action) be brought into the open and translated into the public realm of agonistic politics (Kapila, 2019).

The story of how Mandal produced a new political category and changed that category's relationship to power is well known. But what is less observed is the relative autonomy of this transformation of caste in the realm of politics from caste in the economy (despite Ambedkar's warnings of the dangers of political democracy in the absence of economic democracy). Witsoe's (2013) book, Democracy against Development, shows, for Chief Minister Lalu Prasad Yadav's Bihar state between I999 and 2005, how OBCs were able to take control of political power and, for a period, disrupt the upper-caste-controlled project of state-directed development, but could not institutionalize this power so as to bring equalizing economic gains (cf. Jaffrelot 2006, I87). As Kapila (forthcoming) argues, the pre-eminence of politics as the mechanism for dealing with social matters, and the displacement of social and economic relations of caste onto the issue of reservations, instilled a gap between the political and the economic through which caste inequality is reproduced.

There is an argument by Niraja Jayal (2015), among others, that the extension of public-sector reservations to lower castes, and the restriction of the caste issue to this, was a strategic effort to keep caste out of economics - that is, a form of 'caste abatement', offering political recognition to disadvantaged groups while avoiding economic redistribution, and serving to contain the political discontent surrounding unequal economic opportunity unleashed by the simultaneous (but more stealthy) introduction of neo-liberal reforms, effectively protecting elite class-caste interests now reoriented to private business.

How caste is kept in politics and out of economics (notwithstanding the political need to hold an aspiring urban 'neo-middle class' of OBC

\footnotetext{
${ }^{13}$ There are no easy alternatives to the contentious and simplifying terms 'upper' and 'lower' caste used in cited articles, which, it should be stressed, refer not to any accepted stratification, but to a history of power, domination, and unequal social recognition encoded in vernacular as well as sociological languages.
} 
background (Jaffrelot 2015)) is also explained in studies of the upper-caste/ middle-class politics of caste refusal revealed in ethnographic sites such as Subramanian's (2015) elite Indian Institutes of Technology, in which 'reservations' provide the ground for denigrating unmodern and moribund caste, and the self-serving political entrepreneurs who, as its low-caste purveyors, give caste its unneeded afterlife (see also Deshpande 2013; Fuller and Narasimhan 20I4; Jodhka and Manor 2018). The cultivation of 'castelessness' (invisibilizing upper-caste identities), which Deshpande (2013) argues is an assertion of caste power (see below) particularly encoded in the 'casteless' market economy, Vithayathil sees also manifest in the executive bureaucracy's push-back against the effort to reintroduce caste enumeration into the national census in 201 - an effort that was itself a policy response to lower-caste political pressure challenging 'the invisible privileges of upper castes' (Vithayathil 2018, 477).

There are reasons to see the current administration under Narendra Modi's leadership, with its strong neo-liberal, pro-business, growth-oriented, disparity-concealing (especially of disadvantaged Dalits, Adivasis, and Muslims) character, as keeping the economics of caste firmly out of policy view (see, for example, Tharamangalam 2016; Jaffrelot 2015). There has been cut-back of the various remedial protections, budget allocations, and programmes earlier extended to Scheduled Castes under the rubric of 'inclusive growth' in the Five-Year Plans of the national Planning Commission, which is now replaced by Modi's more technocratic 'NITI Aayog ${ }^{14}$ policy think-tank for his goal of market-driven 'rapid transformation' focusing on matters such as 'developing infrastructure for the industrial corridors and markets' (Engineer 2015). And this managerialist governance is seen as enforced by a combination of authoritarian restrictions on civil-society activism (labelled 'anti-national') and tolerance for identity-building Hindu nationalist anti-Dalit (and Muslim) violence. But the policy turn with Modi might be seen not so much as separating the economy from the politics of caste as building politics on neo-liberal economicsgrowth for all, citizenship as market participation, political democracy as economic freedom (Birla 2015, 467)-appealing to individual market actors and 'seeking transcendence of the social' so as to leave out caste (Kapila 20I5). And, with a 'closing [of] the gap between the economic and the political, the work of difference and identity is increasingly

${ }^{14}$ National Institution for Transforming India. 
becoming the work of culture' (Kapila 2015). What this means is that, within an individualizing market ethics, the cohering interests and obligations of the group or the community are construed in cultural terms as the distinctive 'ethnic' flavour of Brand India's capitalist enterprise, its dharmic or 'karma capitalism' (Birla 20I0, 83-84), not as the relational dynamics of caste within the economy-unequalizing and discriminatory.

Modi's 'conservative revolution' (Kapila 2015) thus combines a language of market transformation with a politics of preserving caste advantage, ensuring caste is protected as private cultural fabric. Alongside the denial of caste, Balmurli Natrajan (2012) and others point to the narration that what remains of caste is benign or beneficial: caste is celebrated community or cultural identity and diversity, part of the vitality of Indian democracy; caste is the culture of business trust. Natrajan aptly regards this stripping caste of its relationality and "camouflaging as "culture" $(2018,298)$ as an instance of Bourdieu's symbolic power - that is, power over a system of classification. Recoding caste as culture legitimizes and protects inherited status, since claims regarding discrimination cannot be made against the preservation of cultural practices (for example, vegetarianism effectively caste-marking/segregating public, social, or residential spaces). ${ }^{15}$ Caste here is a private and domestic matter-a domain of culture not to be 'contaminated with selfish, anti-national, "terrorist" caste politics' (as a Dalit friend summed up the experience of the middle-class conversational exclusion of caste). The caste-based violence that reaches TV screens and newspapers represents an 'abnormality' of normally benign caste (Natrajan 20I2).

In sum, whether premised on compensation for religious and civic disability, or on political empowerment through reservations, or the rejection of reservations in the name of merit, modernity, and market-led development, or on a new conservatism in which caste politics is buried in market economics and 'subcontracted to cultural life' (Kapila 20I5), public-policy discourse directs attention away from the vitality and social effects of caste in the post-reform Indian economy. The past decade has seen a growing Dalit activist challenge to this policy exclusion of relational caste, re-invoking caste and

\footnotetext{
${ }^{15}$ Natrajan (2018) further suggests that, when Dalit activists assert distinctive cultural rights (beef-eating and resisting its ban by the Indian government is his case) rather than mobilization against caste as a socio-political issue of injustice and oppression, they risk inadvertently playing into this caste-perpetuating ethics of managed cultural diversity.
} 
placing caste on the development agenda in the rubric of 'Dalit rights' in national and international fora in ways that are discussed elsewhere (Mosse 2017).

\section{Caste in the village: receding rank and rising politics}

As a prelude to the study of 'Caste Out of Development', I visited the Tamil village in Ramanathapuram District (which I call Alapuram) in which, three decades earlier, I first tried to make sense of caste. I cannot possibly explain the complex transformations of caste, as I have tried to in my book. The Saint in the Banyan Tree (Mosse 2012), but what struck me here was a parallel narrative of archaic caste erased by market relations, and caste rising as identity politics, that rendered undetectable the structural effects of caste on new economic opportunity.

While it has never been possible, for this village, to describe the varied identities and social relations as anything like a 'caste system', the idea of an archaic caste order has always been present as a kind of public representation. Referenced through its symbols, spaces, rituals, and exchanges, this ceremonial order was a way of encoding or loading labour and artisanal services (of barbers, potters, water-turners, dhobis, and, of course, Dalit labourers) as well as the priesthood, ritual, and temple worship with caste identity and hence obligation and social status, such as when a landlord invokes symbols of honour/ subordination from a long-gone royal order and pays artisans or Dalit workers with certain grains and gifts coding rights/duties that are caste-linked, hereditary, and non-negotiable. Exchanges were far too integrated into markets of all kinds for this to mark a kind of non-market, non-monetary, or jajmāni-type relationship (let alone a 'system'). ${ }^{16}$ But such caste coding could extend to various economic transactions such as Dalit tenants' share-cropping (paiku)

\footnotetext{
${ }^{16}$ Fuller (1989) points to the anthropological confusion in studies of jajmani between a 'village establishment' of hereditary caste village officers and servants (the baluta system of the Maharashtrian region, but equally of South Indian kingdoms) and patron-client (jajmani) relations. But, in Alapuram, this was not so much a confusion as a social fact. In the nineteenth century, successful cultivators (of Utaiyar caste) benefitting from secure property rights and regional markets for cotton and groundnut cash crops advanced by the British upturned the old village establishment by privatizing control of land and common property, but then ensured that new dyadic landlord-labourer/ artisan relations took on the form and idiom of an (older) public hierarchy of village
} 
arrangements. This caste-rank coding also provided the symbolic language for challenges to established collective caste power, such as when Dalits grab the festival statues, or change the festival or funeral procession routes, or enter the village temples and teashops (Mines 2005; Mosse 2012) - part of a subordinated group's unfolding drama of change made apparent to them by their own ritual-political acts (Hastrup 2006, I56).

These 'bound-mode' caste relationships, as David (1977), working in Jaffna, glosses the Tamil kațuatụ totarpu (part of what he terms the 'aristocratic schema'), find their counterpart in the 'nonbound-mode' (istamāna totarpu) indicated by voluntary contracts, negotiated rates, cash payment, choice, mutual satisfaction (cantōsam), tradeable skill or art (for artisans or drummers) - in short, what we might now characterize as relations of 'the market' (or a 'mercantile schema'). Not a stable code of conduct, this is a 'frame [that] emerges with the act' (Hastrup 2006, I55) - an implicit reference for artisans and Dalits who, in the early I980s, attempted to change the social meaning of work, replacing caste-referencing grain transactions with the market idiom of cash payments that rewarded individual skill, not inherent (caste) attributes (Good 1982). The liberating idea (rather than actual practice) of transactions freed from caste 'entanglements' and closed off from a nexus of obligations was captured in the Alapuram Dalit dhobi's comment to me in 1983 that 'services paid for in cash have no pollution (tittulu'.

In the early I980s, among artisans, participation in caste-referencing transactions symbolized inclusion in what was represented as the village community or $\bar{u}$, while other, 'market', transactions (albeit practically pervasive) were exceptional to this order (cf. Miller 2002). So when, in I983, Rayappar, a village carpenter (caste/occupation), explained to me the grain-share entitlements (known as cutantaram) he received as his family's hereditary right (urimai) from Utaiyar caste and other farmers (calculated in terms of the pairs of ploughing bullocks of the patron's household) for work on their ploughs and farm implements, his ritual role at house-building ceremonies, and his maintenance of the temple festival chariots (see Mosse 2012, II2, I40), he contrasted this with 'private' work (using the English word) paid for separately in cash (tānikkācu, 'independent money'). Apart from odd jobs on tables or 
chairs (and the like), such work falling beyond the purview of caste-defined cutantaram was that done for outsiders to the village or for Dalits within it (the few owing draft cattle). ${ }^{17}$

By 2009, what had been residual in common representations of the work of village carpenters - the separately paid 'private' work-now seemed to define it, exceptionalizing caste-referencing work. When I enquired from carpenter Michael Acari about cutantaram grain for repairing farmers' ploughs, he quickly replied: ' $[\mathrm{I}$ 'm] not going for slave work (atimai vēlai) nowadays; if [we] work, [we] get wages (küli).' $\mathrm{He}$ explained how no longer was he at anyone's beck and call, readying ploughs in the early hours. 'For kindness (anpukku) we will fall at the feet, but [we] will not submit to power (atikāram),' he said, adding, 'We've become social (cōcalāyirucıl)' (Mosse 2012, 249). Even when describing his ongoing work on processional chariots and door-frame ceremonies (nilai vaikkiratu), he emphasized payment for his skill and knowledge (or possession of an almanac), explicitly disconnected from caste. A changed ethical judgement had refigured the relationship between vēlai (work or current employment) and tolil (caste-specific occupation), the act and the actor (see Good I982). And a market idiom that was earlier an exception or, for Dalits, an aspirational counter to relationships of caste or kattupātu (order, discipline), by 2009, pervasively over-wrote caste-connected work. I was myself rebuked for using phrases signalling old-order practices that were entirely ordinary 25 years earlier. 'We have become social' (cōcalāyirucci) was a common expression, referencing a permissive freedom or market disentanglement from social roles and conventions popularized in films (Mosse 2012, 250).

This moral claim is repeated as Paraiyar (Dalit) drummers negotiate a transactional re-description of themselves as fee-charging professional performers and artists; and the services of barbers, dhobis, potters, and others are relocated from the person-centred exchanges at homes to the impersonal ones of the laundry, shop, stall, and salon in Alapuram's expanding commercial centre - 'an "outside" space where unknowing and unknown outsiders mingle and are served' (Mosse 2012, 25I). In parallel, land tenure dominated by 'bound-mode' share cropping covering 64 per cent of tenanted land in ${ }_{1} 8^{8} 2_{2}-83$ had reduced by a third

\footnotetext{
${ }^{17}$ Since, alongside annual grain as a kind of tithe or retainer, patron farmers also paid cash for the carpenter caste tasks, the relevant distinction is between caste-linked/unlinked rather than payments in kind or cash.
} 
in 1994-95, with a still continuing shift to more market-contractual fixed-rate and land-mortgage tenancy (Mosse 2003, 206).

This expansion of the market as a moral (and physical) space is not in itself recent. However, while over most of the I50-year village history I have studied, market-based claims have been folded back into public representations of collective caste order (or their resistance), by the turn of the millennium, regardless of actual work and dependencies, the common narrative was of a shift towards independence, contract, and individual choice. What has changed is the ideology or framing of economic life, not necessarily its practice (Miller 2002). Today, the old order of caste is firmly placed in the uncouth/enslaved (acinkam/atimai) past by a narrative of the growth of civility (nākarinkam), alongside market freedoms. This was confirmed in a survey and interviews in $2009^{18}$ that revealed a weakening of the discourse of caste honour and group status mobility or the perceived irrelevance of activist narratives of struggle against upper-caste domination. It could be said, following Bate (2009, 79-80), that the 'public' space had become socially unenclosed (or puram, 'outer'), having been denuded of its 'interior' (akam) moral-social-caste character. Certainly, the language of caste distinction is rarely heard in public, partly owing to it being subject to criminal cases, although a persisting 'inner' caste state of caste mind is often suspected amidst the rank-repudiating public forms of respect.

Research in India across regions records a democratization of former markers of social recognition, whether food, dress, grooming, or styles of worship, and a 'declining ability of others to impose social inequalities', as Kapur et al. (2010, 48) conclude from a large-scale study of Dalits in Uttar Pradesh across two sub-districts. But we should be more cautious than these authors are in reading a grassroots narrative of modernization and changed public codes of behaviour as signs of market-driven social transformation. For one thing, as just noted, we should not mistake a change in ideological framing for a change in practice. For another, the invocations of the market are themselves claims that are deeply embedded in caste contentions (cf. Keane 2008). When working a shift from obligated funeral servants to musicians hired at negotiated rates, Paraiyar drummers in Alapuram

\footnotetext{
${ }^{18}$ A survey of 234 individuals (of different ages, gender, class, and caste - mostly Dalit) was conducted by my research assistant, M. Sivan, alongside in-depth interviews by Dr Selvaraj Arulnathan (see Mosse 2018b, 276-83).
} 
were not presenting themselves as economic agents with a now equalized caste-cultural identity, but using the ethics of contract and market exchange to make claims in a relational field of caste power and honour/dishonour. ${ }^{19}$

Third, Dalits in Alapuram would tend to see a caste order not undermined by the market (or gone with 'time's change'-kālam mārirucci - as upper castes often did), but defeated by their political struggle against untouchability in the ig6os and 1970s, armed as they were with education and new economic independence. Then again, achieved equality also produces inequality. The collective action of a Pallar caste Dalit elite may have made it utterly irrelevant who carries the temple statues, enters the teashops, bicycles in the main street, but class inequality widens and a categorical separation of the poorer Paraiyar caste remains, indicative of the persisting division and disparity among Dalits. Moreover, gender inequality persists or is increased since Dalit men not infrequently escaped dishonour by displacing ignominious tasks such as providing free labour and accepting handouts at life-crisis rituals needed to retain upper-caste patrons onto their womenfolk.

With the disappearance of overt practices of caste rank, attention is drawn to subtle attitudinal, communicative, performative, and experiential aspects of caste prejudice and humiliation. These are strategies or tactics produced through interactions (as practical logic rather than social rule) and shaped by the enduring socially deposited attitudes, dispositions, or 'habitus' (Bourdieu I977b) of caste, captured in the Tamil concept of catiputi, loosely 'caste mind', 'mentality', or 'disposition', explored in its variety of new codes and technologies - attire, objects, gestures, sounds and other semiotic forms (verbal and non-verbal) and behaviours (cäti palakkam, caste practice/habit), and interpretation of behaviour-by Murali Shanmugavelan (2018).

Even if the changes in caste practices do not have the wider significance they are often given, it is nonetheless indisputable that the ranked caste order has faded from Alapuram village public life. But,

${ }^{19}$ Unlike urban Dalit activists, none I knew in Alapuram's Paraiyar street expressed interest in reviving parai drumming as a symbol of a distinct Dalit culture - that is, 'honouring the stigma' through performances in Dalit arts festivals. Indeed, these village Dalit musicians preferred to play the standard temple drum and wind instruments (melam and näkacuvaram) as they guarded against the continuing threat of dishonour and servility (Mosse 2012, I83; cf. Natrajan 2018). 
paradoxically, at the same time, caste is more visible than ever. As you climb down from a bus at the roadside commercial centre of the village, you will be confronted by clusters of flags, banners, and posters signalling a proliferation of caste associations, fronts, movements, parties, and NGOs. Competition to occupy public space brings ever-larger wedding or puberty-ceremony banners and statues of caste heroes (ancient and modern) erected in village squares to signal group identity and connections.

But, despite appearances, caste is not reborn within the village in the communalized form that characterizes district or state-level politicswith its rallies, guru pujas, violent street clashes, and lethal police firing. A disjuncture between communal caste politics and the quotidian village is maintained by skilled political entrepreneurs who inter-translate between the two. Thus, Dalit party or movement leaders secure a base of support along caste lines through building reputations for the mediation of disputes - over land, water, or inheritance, mostly not having a caste basis - rather than through contentious caste politics, which dissipates in the village (see Mosse 2012, 259-60). Indeed, as Krishna (2018a) finds from large-scale cross-state surveys, people turn to caste-crossing political entrepreneurs or fixers (naya netas) - a disproportionate number of whom are nowadays Dalits - to bridge the gap in accessing the state (for bank loans, insurance claims, or school places). Expressions of caste are not so much absent as deferred onto public politics. Thus, working in the opposite direction to the politicians, Dalit youth activists work to translate diverse issues into the language of caste contention so as to mobilize external support (from police or politicians), such as when, in cases of individual (not caste-based) disputes over irrigation water, appeals for intervention from the state were made in the arresting language of the threat of caste conflict (cāti piraccanai) (Mosse 2003, 213-I4).

Simplifying a point, one could say, first, that, in the village as in the nation, caste recedes as an archaic system of group rank and honour, with market relations providing the idiom for transactions unbound to caste, and, second, that 'caste politics' now has an autonomy from everyday economic life in the village (that was not the case in the caste struggles of the Ig6os and I970s). But why did a majority (82 per cent) of Dalits questioned in our Alapuram village survey say that caste was a barrier or obstacle (tatai) to their family advancement, meaning economic welfare? How does caste shape opportunity? 


\section{Gaste and market economy}

\section{Caste and opportunity in the village economy}

It is at this point that I need to turn to caste and economy, beginning with the village economy. When Dalit businessman and intellectual Chandra Bhan Prasad says that 'capitalism can destroy the caste system from the inside' (Prasad 2008, 2), he invokes the impact of the post-I990 decline of Indian agriculture and the explosion of non-farm opportunities on caste as an agrarian order. In Alapuram, the abandonment of cultivable land to wood-fuel shrubs, farmers' reliance on crop insurance pay-outs, public distribution rice, or employment-scheme wages as much as tilling the land, and the huge diversification of non-farm business within the village, and work outside, all signal what is a national trend.

This has been tracked in longitudinal village studies, none more thorough than the seven-decade Palanpur project in Uttar Pradesh. Its recent reports (Himanshu et al. 2013) show that an overall decline in poverty is, nonetheless, accompanied by an increase in inequality as the poorest depend upon uncertain casual work in railways, cloth mills, bakeries, bottling liquor, or brick kilns or migrating as construction workers. The impact of such change on caste relations is a complex issue. It is true that the Palanpur researchers find most inequality between households, thus within caste, implying that caste is unimportant to (or made so by) such change. But other studies show the transition out of farming to industry reinforcing caste-based debt and dependency. Ethnographic studies of the diversifying economy of villages show complex and intersecting caste, class, and gender effects. As examples, near the Tiruppur textile hub in Tamil Nadu, Carswell and de Neve (2014) find quite opposite effects - both eroding and entrenching caste inequality - even in close-by and apparently similar villages. In the village hinterland of Chennai, Anandhi (2017, Io6-o8) finds access to casual industrial work freeing Dalit youth from caste-coded (kattupātu) labour dependence. However, peri-urban precarity also deepens gender inequality. Young Adidravidar/Paraiyar (Dalit) men in irregular work in Chennai prefer periods of unemployment to degrading agricultural labour, but their irregular factory work is insufficient to meet household needs that are elevated by the consumption expectations, education fees, and dowry payments born of new status ambitions. Meanwhile, investment in a new Dalit modernity and masculinity involves 'upper'-caste-class gender notions regarding status, honour (mānam), and respectability (mariyātai) that bear 
down on Dalit women who carry an extra burden of income earning (agricultural labouring, cattle rearing) and domestic work, while being subject to patriarchal controls. There appears, then, an inverse relationship between developing caste social status and women's status (Anandhi 20I7, I09), as well as new assertions over both the older generation and the inferiorized Arunthathiyar caste (in the village studied) who remain locked in dependency relations with dominant-caste landowners.

The factors accounting for the different impact of labour and other markets on caste and caste on rural markets are varied-histories of land control or reform, urban proximity, caste demography, and political mobilization among them-and do not permit generalization about the erasure of caste effects in the post-liberalization rural economy (for example, Himanshu et al. 2013; Lanjouw and Rao 20II). Observing caste effects in the economic life of today's villages is not easy. What struck me as my assistant and village resident, M. Sivan, revisited 6o Alapuram families of different castes to ask about the route to work and qualifications of their sons and daughters was that, despite being a receding determinant of standing in the village, caste was important in structuring opportunity in the world beyond. Caste was an alloyed effect, bound up and disguised in the mobilization of capital, dowry payments, or networks into institutions (of government, the Church, and so on). Caste was embedded in relations of kin, friendship with class-mates, priests, or agents mediating work abroad, and, of course, marriage, through which entry into higher education, urban employment, or business was navigated and which reproduced the historical privileges of caste such as inherited wealth (land) and productive networks.

A deepening urban-rural opportunity divide (see Krishna 2018b; 20I7) amplified this significance of caste. In Alapuram (as elsewhere), upper-caste families (for example, Vellalars, Chettiyars) were the first to exploit connections for more lucrative futures in regional towns and cities, eventually selling up and relocating out of the village in the I970s and I980s, while Dalits sought economic mobility by investing in farming livelihoods. But the later reduction in low-skilled jobs (with factory closures or mechanization) and raised pre-qualifications for urban formal-sector employment (in terms of skills, cultural capital, and connections) (Krishna 2018b; 2017) gave caste renewed importance to those seeking exit from the limited opportunities of the village. 
Caste was now mobilized not as public status, but as a network resourcenot for the preservation or enhancement of the status of the group (as in earlier conflicts that canalized economic opportunity into the idiom of ritual rank, cf. Bailey 1957, 270), but in support of individual mobility (redirecting symbolic capital to economic opportunity). The banners and posters, the marriage halls, scholarships, and prizes for 'topper' students of regionally linked subscription-collecting caste associations were not organizing for village or regional political power so much as networking for access to the regional economy. (Of course, the two interlink.) To borrow Kirsten Hastrup's distinction, here, caste is less 'substance' - that is ethnicized collective identity in struggles for political power - and more 'set' - that is, looser, intentional, strategic network, pragmatically realized in the search for jobs, skills, marriages, and support in local dispute mediation (Hastrup 2006, $156-57$ ).

It is poverty in this resource of caste (capital and connections) that leaves a proportion of Dalits in economic insecurity. Indeed, while their fathers organized against caste exclusion from public places like teashops or temples, and to carry the festival statues of the saints, in a field of caste honour, Alapuram Dalit youth mobilized around the privileges, chits, and tickets for access to the economy, targeting the gatekeepers of opportunity such as schools, colleges, or the Church.

My final point from the village is that this shift from honour to opportunity - from action around group status to group action for individual mobility-decreases the visibility of caste effects. Caste reworked as private connections and capital is not easily perceived as such. Among the Alapuram Dalits surveyed in 2009, the expectation of equal treatment (for example, in schools and colleges) was firm and, in accounting for outcomes (jobs and so on), they emphasized personal talent, qualifications, skill, good luck, and God's blessing, alongside helpful priests and patrons, even though it is well understood that the route to the good bishop is by way of his caste-networked secretary (Mosse 2018b, 279). Despite their own insistence that these are days of civility and equality, the majority of Dalits surveyed nonetheless expected ill-treatment and disrespect as they sought work or other breaks and could not imagine escape into the casteless anonymity they desired or into 'mere poverty' (Roberts 20I6, 55). In fact, poverty itself exposes people to caste humiliation and our survey showed that the poorest and women were most incentivized by ill-treatment to try to conceal their caste when labouring in distant places. 
What I am suggesting is that, in the nation and in the village, there appears to be a disjuncture between the public narrative of caste (as market-eroded tradition and identity politics) and the processes of caste, which are firmly part of the modern market economy. But there remains uncertainty about the nature of these processes, their harder-to-detect effects, and how they are to be discovered.

Ethnographers already knew that those who controlled the village land gained advantages in the regional and industrial economy, and that caste networks in cooperatives, sand-mining cartels, in companies, and the Church are critical to the functioning of business, bureaucracy, and education (Shah et al. 20ı8; Witsoe 20ı8; Jodhka and Manor 2018). And that those drawn or pushed out of agriculture are sorted into work graded by skill, security, danger, or toxicity in caste-related ways, the gender divide allocating the worst work to Dalit women, who carry the greatest burden of social degradation (for example, Carswell, de Neve, and Heyer (2018) on the Tiruppur garment industry).

But identifying caste effects in the wider economy that are visible only in the aggregate and which are not easily (or at all) traceable to the agency of caste collectives, or action within a framework of caste, requires different instruments - in particular, the large-sample surveys $^{21}$ and statistical methods of economists, who have perhaps done more than anthropologists to identify the modern 'Grammar of Caste'- to use economist Ashwini Deshpande's (2017) title - even though the caste-merging block categories of analysis of national datasets- SC, ST, $\mathrm{OBC}$, and General - are sociologically crude and sometimes misleading.

At the scale of national data sets, it becomes clear that post-reform development and its economic diversification have not, as regards employment, broken the association of 'upper' castes with higher-status professions and Dalits with manual and casual labour. For the postreform period, the data reveal glass walls against Dalit occupational mobility out of caste-typed roles or low-end service trades into more profitable ones, or self-employment (Das 2013). A widening caste disparity in earnings at the top of the income distribution, and in access to the

\footnotetext{
20 These sections on caste in the economy, in the labour market, and in business adapt and summarize a more detailed review of literature elsewhere (Mosse 2018a).

${ }^{21}$ Data sets include those of the Indian decennial censuses and surveys such as the National Family Health Survey, the National Sample Surveys of India, and the District Level Household Survey of India.
} 
most prestigious jobs, indicates a 'glass ceiling' effect (Deshpande 2017, $\mathrm{xv}$ ). The intersections of caste and gender mean that Dalit women, with comparatively higher (although declining) participation rates in the labour force, are particularly restricted in job mobility (Deshpande 2017; Das 2013). In parallel, the rapid expansion of private business with a two-thirds increase in enterprises since 1990, and half the workforce self-employed by 2005 (Harriss-White, Vidyarthee, and Dixit 2014, 40, 5I), has not brought freedom from caste effects. The Dalit share of enterprise ownership is disproportionately small and initially decreased post reforms before rising by 2005 (Iyer, Khanna, and Varshney 2013, 56). Data reveal the business economy as a caste-structured field and Dalits (often as first-generation entrants) are firmly at the bottom, running rural petty shops, as dealers or agents (Harriss-White and Vidyarthee 2010). To the 'glass-ceiling' effect in salaried employment is added the 'sticky-floor' effect of a widening caste gap in earnings at the lower end of income from self-employment (Deshpande 2017, xxiv).

The social processes underlying these patterns are still under-studied, but let me highlight three kinds of caste effect: first, the differential valuation (ranking) of occupations and derivatively markets; second, the effect of categorical distinctions, caste identity, and caste networks; and, third, the combining of these as discrimination. These processes are not distinct, but are interdependent and build on each other.

\section{Occupational ranking}

Evidence for the persisting differential valuation of work, workers, businesses, and markets is strong - a fact overlooked by the World Bank when its $201 \mathrm{I}$ report on Poverty and Social Exclusion in India (2011, I18) concluded with Prasad's optimistic words: 'Along with a new tool which neutralizes caste, the sweeper [in the shopping mall] turns into a housekeeper, looking more like a paramedic than a traditional sweeper. In one stroke, the market has liberated the broom from its caste identity, and the occupation has become caste-neutral' (Prasad 2008, 29).

The caste-typing of jobs such as Dalit labour in sanitary work or, for that matter, Brahman cooks and suppliers in the South Indian restaurant trade (Iversen and Raghavendra 2006) are only the most obvious examples of the pervasive caste effect in work and occupation. Identity-bound work particularly characterizes the most stigmatized occupations. The placing of the social cost of disposal of noxious waste onto undervalued humans is found in Barbara Harriss-White's (2017, IIo) study of the informal waste economy of a Tamil town and is something well known from the unprotected work of dealing with 
human excreta known as 'manual scavenging', prohibited by law but still assigned to the lowest Dalit castes (Singh 20I4). The underlying attitudes to purity, pollution, and the valuation of shit-related tasks as degrading and associated with untouchable caste status account for the failure of rural pit latrines (requiring manual emptying - a task only for Dalits) and persistence of globally high rates of health-damaging open defecation in India (Coffey et al. 2017; Coffey and Spears 2017). Such caste-typing of waste work is carried over into new sanitation and sewer programmes (Tam 2013) and within the waste-recycling businesses studied by Gill (2012) in Delhi; the more inferiorized the market (for example, for un-segregated part-organic waste as against segregated plastics), the more linked to caste-occupational pasts. An enclaving of Dalit business in such low-status or shunned markets is also an effect of their exclusion from other sectors. Across the economy, an occupational ranking of markets differentiates Dalit access. While sectors such as mining/quarrying, construction, and transport are relatively open to Dalit businesses, health and education, food, hospitality, and the service sectors are found to be relatively closed to them (Harriss-White, Vidyarthee, and Dixit 2014, 67; Thorat, Kundu, and Sadana 2010, $320-2 \mathrm{I})$.

\section{Categories and connections: caste identity and networks}

The caste segmentation of labour markets and business indicates a cultural logic embedded within and perpetuated through economic activity. It is demonstration of the fact that, in economic transactions, people are treated differently according to their social identity - an idea central to the field of 'identity economics' (Akerlof and Kranton 2010). More specifically, Charles Tilly (I998, 2010) argues that transactions involving greater and lesser beneficiaries generate categorical boundaries that gain efficiency by coinciding with unequal categories of wider society (for example, of gender or caste). Systems of labour recruitment operating on social categories (independently of individual characteristics) then restrict mobility to more skilled and better-paid work. I have noted such categorical effects in research on the construction sites of western India that distinguish Saurashtrian bricklayers from Dalit/Bhil casual labourers, ensuring that, even after 25 years' work on construction sites, in stone quarries, lime kilns, and brick fields, a Dalit (or Adivasi) labourer has no chance of getting skilled or better-paid work (despite a shortage of skilled labour) (Mosse 20I0, II26). Tilly's (I998) counterpart 'opportunity hoarding' is found at the upper end of employment where, for example, Upadhya (2007) argues the IT industry consolidates 
occupational privilege by recruiting from middle-class/upper castes, providing new and well-paid employment opportunities.

The occupational differentiation produced by such 'categorical exclusion' and 'opportunity hoarding' becomes self-reproducing by influencing skill acquisition (Tilly 200I; 1998; Munshi 2016a, 27). The manner in which caste identity works here as an imposed societal categorization also has effects through constituting subjectivities and self-worth, evidenced, for example, when Dalits (in a national sample) are found to perceive lower levels of earning as remunerative (Goel and Deshpande 20i6). However, we also know from Hoff and Pandey's (2006) widely cited experimental studies how such caste identity is not a fixed attribute; what is important is the contextual making-salient of caste. In their research, for example, when (and only when) caste identities were publicly announced before a problem-solving experimental task, the performance of Dalit students was negatively affected in comparison to that of non-Dalits (the so-called 'stereotype threat effect'). That is to say, caste identity is not substantial and stable, but frame- or context-dependent in its effects.

This requires attention on how contexts make caste salient - how caste is cued. In business, for example, caste may be cued to seek competitive advantage. Thus, a Dalit woman supplying lunch boxes to Mumbai offices informs Aseem Prakash:

There used to be huge demand for the food I prepared. However, when the popularity of my food affected the business interests of Manjrekar [an upper caste], he went and told everyone that I belong to a lower caste. Thereafter, the demand for my food reduced by more than half (Prakash 2015, 72).

The modern power over Dalits is indeed the making-salient of caste and all its social judgements and categorizations, through everyday gesture, phrase, or phone ring-tone, which, when it happens amidst the expectation of equal treatment (for example, in business, in a college or university), is experienced as shocking, humiliating, even traumatic. ${ }^{22}$

${ }^{22}$ Such 'dignity humiliation' - the refusal of claims to equality that can be contrasted to the 'honour humiliation' involved in ritual humblings and public enactments of graded status and Dalit inferiority in village life (see Lindner 2010) - we have found (in collaborative research led by Sushrut Jadhav et al. (2016)) is a source of distress, turning universities into places of defeat for ambitious Dalit students or faculty. This has a bearing on the tragic death by suicide of talented students in elite institutions that has been a rupture in the narrative of casteless modernity. The message Dalits receive is 
Caste identity is also made salient (often, for Dalits, inescapable) by the significance and role of caste networks in economic life, including in the caste differentiation of labour markets and businesses. Thus, network-based labour recruitment through gang leaders and foremen, familiar in the colonial mills, railways, factories, or plantations, and their present-day equivalents, including the construction-site and brick-field destinations of 'super-exploited' seasonal migrant casual labourers (Shah et al. 2018), produce caste-segmented labour forces and underline the necessity for (or inescapability of) categorical membership.

The equivalent role of caste networks in the control of business is well known from a history in which castes dominant in nineteenth-century trade moved into manufacturing, followed (post i99I) by agricultural castes (Damodaran 2008; Chari 2004; Munshi 20I6a, I4-I5). Caste networks are especially important in business regulation where risks are high, formal institutions weak, and 'selective trust' at a premium, whether the low-end, high-turnover opportunistic Gujarat garment industry (Harriss 2003) or the high-end diamond industry in Mumbai and Antwerp (Munshi 201I).

Strong caste networks are also a feature of shunned markets where Dalit businesses are found, such as leather, sanitaryware, and in the waste economy mentioned earlier, but generally Dalit entrepreneurs suffer the costs of exclusion from networks of business through which information flows giving preferential rates or facilitating the informal transactions with officials needed for business (Prakash 2015). Such support networks for business are hardly compensated for by their own Dalit Chamber of Commerce and Industry $^{23}$ whose aspiration to 'fight caste with capitalism' mostly speaks to a Dalit business elite far removed from the majority, or by reliance on NGOs or state experiments to diversify government procurement (Vidyarthee 20I6).

If we think of caste as a resource, it is perhaps most obviously as durable and wide-reaching networks of potential or actual kin offering access (to jobs, business, the state), protection (social insurance in crisis), and control (over resources)-networks that fall beyond state regulation

that, if they are to be present in a privileged space that is not properly theirs (the elite university), it can only be as non-meritorious marked reservations 'category' persons. For findings on how, in Indian universities, caste-categorical judgements about capability, worth, or cultural difference bear on important decisions on friendship, love life, and careers (always moderated by other factors of class, gender, religion, or region of origin), see, for example, Pathania and Tierney (2018).

23 http://www.dicci.org/about.php (accessed 24 September 2019). 
(Munshi 2016b; Hoff 2016). The necessity for caste-belonging is demonstrated by the low and stable rate of out-marriage at just 5 per cent in rural India and that still 70 per cent of educated middle-class Indians marry broadly within caste (Munshi 20I4; 20I6a; Banerjee et al. 2013). However, the effectiveness of networks is variable across caste categories. Deshpande (2018), for example, finds in Delhi that upper-caste secondary-school graduates who used networks in job searches did better than those who did not, but Dalit graduates who used caste networks did worse than those who did not. The extent to which Dalits are actually disadvantaged by their networks is unclear and sometimes weak networks lend advantage. Luke and Munshi (2011), for example, found that Dalit tea-estate workers in South India with weaker caste/marriage networks in their ancestral villages had greater investment in education and higher women's income earning. Sometimes, as Craig Jeffrey et al. (2008) show for rural Uttar Pradesh, network building by educated Dalits is a response to blocked access to jobs or business (the case in Alapuram village, too). But Dalit networks that are strong politically 'are often weak in terms [of the informal processes that] garner access to markets', capital, and jobs (Das 20I0, 33I).

Significanly, Munshi and Rosenzweig (2009) show that caste networks also have affects of their own. For example, the costs of exiting village caste networks explain India's low rural-to-urban migration (despite high wage differentials) and networks are strongest when there are few outside options, such as those in brokered labour recruitment (Munshi 2014). Moreover, external change, such as in the structure of the economy, can impact on, even reverse, the positive effect of a caste network, meaning, for example, that caste networks that facilitated the mobility of one generation of Dalit men from villages into formal-sector blue-collar jobs in Mumbai limited the opportunity of the next, as boys were channelled into network-linked vernacular-language schools, excluding them from new white-collar jobs in the post-liberalization economy, accessed, in fact, by young women through high-return English-medium education (Munshi and Rosenzweig 2006).

\section{Discrimination}

Occupational ranking, categorical exclusion, opportunity hoarding, and the work of networks combine in the third caste effect: discrimination. Consider employment discrimination. It is well understood that Dalits face barriers to gaining qualifications within school and university systems, including just when the premium to education rose in the post-liberalization period (see studies reviewed in Mosse 2018a, 426-28, 
$43^{\mathrm{I}-32)}$, but, beyond this, the return on qualifications in terms of employment, higher wages, or self-employment among Dalits is smaller (Das 2013, I; Deshpande 2017, 75-82). Asking why equivalently qualified Dalits are less successful points to discrimination, especially in recruitment and role allocation rather than wages (namely different pay for the same work).

Scholars distinguish different kinds of discrimination-direct/ intentional, statistical, structural, systemic, institutional - which will not be explained here (see Wrench 2016). Suffice it to say that there is good evidence that the Indian labour market discriminates both directly on caste identity and on imputed characteristics (statistical discrimination). First, studies using fake GVs signalling the social identity of identically qualified candidates find that applicants are sorted by would-be employers explicitly by caste, especially in private firms, in certain sectors (more so in call-centre than software-industry jobs) and when recruiters are male and Hindu (Thorat and Attewell 2007; Siddique 20II; Banerjee et al. 2009; Upadhya 2007; Das 2013). It is also clear, second, that the job market implicitly demands of applicants traits, skills, linguistic, and cultural competences that the education system does not explicitly give and that come from families transmitting a dominant class-caste culture bundled as individual 'merit' (and indirectly signalled by caste identity) (Bourdieu r977a, 494; Munshi 2016a, 27).

Such discrimination then produces caste-differentiated expectations, since upper-caste/class graduates experience prejudicial norms and networks as casteless merit, whereas Dalits find themselves negatively identified with their caste background at every turn (Deshpande 2013; Deshpande and Newman 2007). These expectations contribute to the reproduction of occupational differentiation including through the above-mentioned effect on self-worth (Goel and Deshpande 2016). Finally, caste-based discrimination can be produced endogenously by markets (Basu 2017). Since much work is interactional, societal prejudice impacts on the productivity of those discriminated against, embedding perceived differences of worker effectiveness across caste. The market mechanism of competition then itself perpetuates caste discrimination.

In the business economy also, competition feeds direct discrimination, for example, when Dalit entrepreneurs find that rivals leverage consumer discrimination against them, especially in certain sectors such as food (as noted), health, and education-related businesses. Aware of this threat, a Dalit entrepreneur tells Surinder Jodhka: 'While most other businesses or enterprises are known by the service they provide or 
goods they sell, our shops are known by our caste names ...(Chamar's shop, or factory of the Chuhra)' (Jodhka 2010, 46). Many try to hide their identity (half in Jodhka's survey of in8 Dalit entrepreneurs in two urban centres of Haryana and western Uttar Pradesh). Discrimination more generally contributes to restricted Dalit business access to capital or collateral, to premises, infrastructure, raw materials, and markets, ensuring that, while Dalit businesses are diversifying away from stigmatizing activities in rural areas, prejudice still enclaves them in urban areas (Jodhka 2010; Iyer, Khanna, and Varshney 20I3; Thorat, Kundu, and Sadana 20Io; Harriss-White, Vidyarthee, and Dixit 20I4; Deshpande 2017, xviii). And, in some cases, the barriers to self-employment, like those to professional careers, contribute to Dalits' withdrawal into unemployment (Das 2013).

The extent of discrimination (like Dalit business access) is uneven across sectors; it is also (for reasons still poorly understood) uneven across the country. Loosely speaking, Harriss-White et al. (2014) map three regional variants: a 'northern' belt with low general business activity and low Dalit participation; a 'central' belt with high activity and high Dalit participation; and a 'southern' belt with high business activity but low Dalit participation. State policy, such as on poverty reduction, is a poor explainer of this variation, but so are education levels, urbanization, growth rates, Dalit political success, or anti-caste movements, especially of the southern entrepreneurial region having strong discrimination against Dalit business (Harriss-White, Vidyarthee, and Dixit 2014, 59).

In such a context, setting up a business, however small the stall, the salon, or the service, may be taken as a social assertion, as is entering an elite institution and profession; it represents a challenge to the implicit attitude that Dalits as a category are expected to be subordinated labourers and their entry into privileged occupational spaces is socially transgressive (Harriss-White n.d.; Nate Roberts, personal communication). The outrage that Dalit economic success or competition from below can provoke is manifest in the increasing scale of humiliating violence against Dalits, nowadays uploaded onto social media - attacks that are shown by Sharma (2015) (using a decade's crime data 200I-IO) to correlate with narrowing gaps between the standard of living of dominant castes and Dalits.

What can be concluded about caste in the post-liberalization economy? As seen in the village, caste is subject to powerful forces of change. Ideas and practices of markets bring expectations of equality and, in many contexts, an emphasis on skills, experience, and competence have 
replaced the ascriptive characteristics and complementarity of caste. But, at the same time (and in the same places), caste-based identity, networks, interactions, and judgements are unavoidably part of the way many markets work, as caste 'transforms itself as a regulative structure of the economy' (Harriss-White and Vidyarthee 2010, 318). I have mentioned only some of the many recent studies of caste effects in sectors ranging from the housing market that caste-segregates urban space (Thorat et al. 2015; Singh and Vithayathil 2012) to contracting for major road construction (Lehne, Shapiro, and Vanden Eynde 2018). The power of caste as a social structure of regulation in the economy, controlling the supply and price of goods, rents, and labour, and influencing the operation of formal institutions and the market, as Harriss-White (2003) argues, comes from the fact that the part of the economy that involves the majority of people is informal, without regulation by legal-institutional structures of the state. As such, these influences 'remain hardly touched by liberalization' (Harriss-White 2003, 24I). They also evade attention in the national discourse and political action on caste, as anxieties about success in the post-reform economic order continue to focus on affirmative-action reservations, mobilizing increasingly militant activism both against reservations and to extend them (Deshpande and Ramachandran 2017). ${ }^{24}$

It is the character of caste that its effects are experienced quite differently (often inversely) by upper castes and Dalits. For Dalits, it has become clear that caste in the economy works as a 'structure of discrimination' restricting opportunity and deepening inequality (Harriss-White and Prakash 2015). In parallel, for others, caste works as a structure of advantage (a 'social structure of accumulation' in Harriss-White's (2003, 239) terms). Indeed, modern caste persists in the age of the market because of its advantages - its exclusions are opportunity-hoarding gains for others, even though, constitutionally and legally, caste is recognised only as a source of disadvantage, never a source of privilege (Subramanian 2015, 296; Deshpande 2013, 36).

${ }^{24}$ I have reviewed recent work on the effectiveness of affirmative action elsewhere (Mosse 2018a), noting that, given ongoing unequal opportunity and market- and non-market-based discrimination, the justification for current reservations and their extension to the private sector would be strong. Counter-arguments that reservations perpetuate caste speak more powerfully of the invisibility guaranteed to processes of caste in accumulation within ordinary, mostly informal, economic life (Thorat, Naik, and Tagade 20I6; Deshpande 2013). 
As a source of privilege, caste provides 'favorable categorical memberships and helpful connections' (Tilly 2007, 47). To varying degrees, upper-caste identity embeds privilege (of power and control over material and symbolic resources) as a transmissible capacity, as Deshpande (2013, 33) puts it, to transform their accumulated 'caste capital' into 'modern capital' (property, higher qualifications, professions, and so on). Ethnographic demonstration of this is found in Fuller and Narasimhan's (2014) study of the caste-class privilege of Tamil Brahmins and Subramanian's (2015) exploration of the role of institutions such as the Indian Institutes of Technology (IITs) in manufacturing technical skill/merit from caste privilege. In this sense, privileged caste identity offers tangible benefits. Even for those who are without power, money, or influence, upper-caste identity offers the political advantage of not being Dalit - not being at the bottom of the socio-economic order - that gives the poor as well as the middle class a stake in caste discrimination (cf. Harris 1993, i760). Perhaps, above all, caste advantage is the 'settled expectation of relative [upper-caste] privilege as a legitimate and natural baseline' (Harris I993, I7I4). Cherly Harris (reference to whose work on whiteness here I owe to Nate Roberts, personal communication) analyses such 'settled expectation' as a kind of property - in that case 'whiteness as property' (Harris I993). An interest in the protection of unmarked advantage (as property) uses putatively objective measures of merit to protect conditions of unfair competition in the market so that 'what is unequal will be regarded as equal in law' (Harris I993, I777), while 'the exclusion of subordinated "others" was and remains a central part of the property interest in whiteness' (Harris 1993, 1758). As Harris suggests, this 'protection of the property interest in whiteness is achieved by embracing the norm of colorblindness', which 'denies the historical context of white domination and Black subordination' (Harris I993, I768). Affirmative action, Harris points out, is resisted because it serves to 'de-legitimate the assumptions surrounding existing inequality' (Harris I993, I778).

A loosely parallel property interest in upper-caste advantage is protected through investment in claims to castelessness, where accumulated privilege allows self-fashioning independently of caste in terms of merit, modernity, and middle-classness (Deshpande 2013; Mosse 2015; 2020; Vithayathil 2018). At the same time, Subramanian observes a self-branding Tamil Brahmin exceptionalism that 'makes [casteless] merit into a form of [Brahmin] caste property' (Subramanian 20I5, 310). The point is that upper-caste status confers the capacity to 
avoid the imposed salience of caste identities that are nonetheless invariably detectable if not flaunted (for example, through caste surnames). As Deshpande puts it, '[u]pper caste identity is such that it can be completely overwritten by modern professional identities of choice, whereas lower caste identity is so indelibly engraved that it overwrites all other identities' (Deshpande 2013, 32). Dalits who cannot anonymously encash caste as advantage can only deploy it politically in ways that make caste hyper-visible in their claims (Deshpande 2013, 32).

\section{Caste as a social structure of the economy}

I began this article by asking what we learn about caste observed from the point of view of the modern economy rather than religious ideology or political competition. For one thing, once caste is untethered from 'traditional' cultural ideas or agrarian order, it is easier to observe caste in history, as Habib (2002) does, in terms of its capacity to adapt to different social formations and labour processes, being itself formed through processes of urbanization, new markets, the multiplication of productive skills, technologies, specialists, types of manufacturing, and commerce, found in the economic transformations of the fourteenth century, as much as the nineteenth or twenty-first centuries. Also in the historical rear-view are the caste effects of enabling access to productive resources, markets, education, as well as controlling labour, lowering wage costs, restricting mobility, and containing resistance.

Considering caste in terms of general social processes such as identity discrimination, categorical exclusion, and opportunity hoarding provides a perspective on caste effects today that allows comparison with race, ethnicity, and other identity-based (and gender-intersecting) inequalities. $^{25}$ Of course, this is entirely compatible with appreciating the significance of emergent and enduring cultural values that, for example, underpin the ranking of occupations, spaces, markets, and people and that ideas of purity and pollution remain alive in judgements and interactions in the marketplace, as Buswala Bhawani's (2016) recent work on 'the bazaar and the butchers in Rajasthan' makes clear. Invoking the metaphor of the network (if not formal network analysis; see Mosse 2018a, 432) avoids caste as an over-determined,

\footnotetext{
${ }^{25}$ On the recent anthropological re-engagement with comparisons of caste and race, see Pandey 2013; Still 2015; Fuller 20II; Roberts 2017.
} 
totalizing cultural or political concept, or presuming an independently definable caste logic. After all, caste is seen to break down and reform in new ways, and caste networks are 'cut' for different purposes (Strathern I996). ${ }^{26}$ Caste-influenced interactions take genuinely new and unanticipated forms and often interact with, or orchestrate, other processes that include or exclude in their own right and where caste may be absent (or concealed) from actors' frames of reference. And caste effects may also be lodged within interactional systems as an endogenous product of market relations (Basu 2017). As network theorists John Mohr and Harrison White put it, 'institutional resilience is directly correlated to the overall degree of structural linkages that bridge across domains of level, meaning, and agency' (Mohr and White 2008, 485). And it is this flexibility of caste, not continuity of a particular cultural form or social institution, in which lies the resilience of caste (Mosse 20i8a, 432).

What is required is indeed a multi-level view of caste as a social structure of the economy made evident at the macro level through large-sample surveys and at the micro level through reflexive observation of interactions that reveal caste-socialized subjectivities, the wider social structure being, as it were, incorporated as attitudes, thoughts, and historically embodied dispositions - that is habitus. In Bourdieu's terms, caste is both part of such subjectivities and the social field that produces them with its unequal distribution of material and symbolic capital (Bourdieu 1977b; 2000; Swedberg 201I). Also, from Bourdieu, we have a methodology that uses ethnographic insight to ground/frame statistical analysis of large data sets, initiating feedback loops between statistical practice and social experience allowing generalization - that is, discovery of a 'grammar' of caste and putting caste society on display (Swedberg 20II; Deshpande 2017; Mair, Greiffenhagen, and Sharrock 20i6).

Bourdieu, finally, helps us think about the problem of the economy that is not a socially disembedded system of rational Homo economicus - certainly not one that can simply be re-embedded in social networks. The market economy is, Bourdieu suggests, itself a socially constituted 'system of embodied beliefs', values, dispositions, tastes, aptitudes, as well as categorical belonging and network connections (Bourdieu 2000; 2005) ${ }^{27}$

\footnotetext{
${ }^{26}$ A point made to me by Sara Besky (personal communication).

${ }^{27}$ Bourdieu's capitalist economy has a subjective-cultural as well as an objective element. 'Economic behaviour is influenced by the understanding that people have of
} 
and it is one that, in India, is not separate from those of caste (with all its intersections with class and gender) in that the construction of 'rational economic agents' produces systematic discrimination against lower-caste economic agents who find themselves 'devoid of the dispositions tacitly demanded by [the] economic order' (Bourdieu 2000, I8) to which the upper-caste middle class are selectively adapted. It matters less whether discriminatory effects are intentional, statistical, or even endogenous, as caste arbitrarily becomes a 'focal point' of productivity and coordination in a rational market (Basu 2017).

In other words, Dalits are discriminated not by caste as a set of relations separate from economy, but by the very economic and market processes through which they often seek liberation through market 'framings' (Callon 1998) and through the processes of a social field that are concealed (misrecognized) by the pervasive ideologies of the market and its freedoms - indeed by the economic habitus that operates as a 'kind of cultural and social screen between the actor and reality' (Swedberg 20II, 75).

\section{Conclusion}

In recent years, the market economy has become the privileged site for political investment in Indian modernity and development. I have argued that the neo-liberal framing of social transformation separates out caste as a matter of religion/culture or special-interest politics, making it harder to acknowledge caste as a social structure of the modern market economy itself that works to help some get ahead and sorely burdens others, as indeed does the way of talking or not talking about caste.

Obstacles to taking better account of modern processes of caste are to be found in the cultural logics that frame the conceptualization of caste and of economy, as well as the construal of caste in policy discourse as a residual problem of social disability, but equally in policies that focused public attention on caste in the I9gos effectively serving to keep caste in politics and out of economics, and the more recent purifications

their economic actions; and this understanding includes values and morality' (Swedberg 2011, 70, 73). The 'market' is 'the totality of relations of exchange between competing agents' including relations of power, force, and the unequal distribution of capitals that make the economic field (Bourdieu 2005, 204 in Swedberg 2011, 74). 
of the market economy that subcontract caste to culture. In the village, caste has become a less obvious collective frame for social life. Economic transactions and mobilities are no longer folded back into public representations of caste ritual order (the former site of varied struggles over group status), civility and market freedom being the emergent public discourse (behind which caste-inequality dispositions are reproduced). Meanwhile, public expressions of caste are deferred onto caste politics - the movements or parties that are kept autonomous from everyday economic life now oriented towards a widening range of opportunities for which caste, in the different guise of a network resource, is mobilized.

It is the aggregate effects of caste in this form-unobserved by certain fields of scholarship, policymaking, and actors themselves - that are the focus of recent survey-based research. Such research draws attention to some key effects of caste - the occupational and market ranking, categorical and networks effects, and varied levels of discriminationthat are embedded as self-reproducing structures of the Indian market economy. Equally, caste as advantage (or a kind of property) in the market economy is reproduced through norms and claims of castelessness that place the burden and blame for caste on the disadvantaged groups. This awakens need for new tools and concepts to understand contemporary caste processes, to rethink caste not as one thing wholly independent of other relations (such as gender or class), but as identifiable effects and processes that require scholarship, especially in relation to the market economy, and against the grain of political and policy refusal.

This is a challenge provoked by the rise of Dalit politics that has shifted concern from the colonial disguises of Orientalism to the caste disguises of the market economy - from the problem of caste reification to that of caste refusal. It is a challenge to attend to the continuing disjuncture between the public narration of caste as outside the realm of 'the modern' and the processes of caste that are firmly part of the modern and that reproduce discrimination while denying legitimacy to its public resistance.

\section{References}

Akerlof, George A., and Rachel E. Kranton. 2010. Identity Economics: How Our Identities Shape Our Work, Wages, and Well-Being. Princeton: Princeton University Press.

Ambedkar, B. R. I947. 'States and Minorities'. In Dr Babbasheb Ambedkar Writings and Speeches Vol. I, edited by Vasant Moon, 38I-449. New Delhi: Dr. Ambedkar Foundation. 
Anandhi, S. 2017. 'Gendered Negotiations of Caste Identity: Dalit Women's Activism in Rural Tamil Nadu'. In Dalit Women: Vanguard of an Alternative Politics in India, edited by S. Anandhi and Karin Kapadia, 97-130. Abingdon, Oxon \& New York: Routledge.

Bailey, F. G. 1957. Caste and the Economic Frontier: A Village in Highland Orissa. Manchester: Manchester University Press.

Banerjee, Abhijit, Marianne Bertrand, Saugato Datta, and Sendhil Mullainathan. 2009. 'Labor Market Discrimination in Delhi: Evidence from a Field Experiment'. Fournal of Comparative Economics 37 (I): I4-27.

Banerjee, Abhijit, Esther Duflo, Maitreesh Ghatak, and Jeanne Lafortune. 2013. 'Marry for What? Caste and Mate Selection in Modern India'. American Economic fournal: Microeconomics 5 (2): 33-72.

Basu, Kaushik. 2017. 'Discrimination as Focal Point: Markets and Group Identity'. Forum for Social Economics 46 (2): 128-38.

Bate, Bernard. 2009. Tamil Oratory and the Dravidian Aesthetic: Democratic Practice in South India. New York: Columbia University Press.

Berg, Dag-Erik. 20I4. 'Scheduled Castes Policies in Interstate Perspective: Constitutional Power, Argumentative Practices, and Governance in India'. India Review I3 (3): 235-50.

Birla, Ritu. 2008. Stages of Capital: Law, Culture, and Market Governance in Late Colonial India. Duke University Press.

Birla, Ritu. 2010. 'Vernacular Capitalists and the Modern Subject in India: Law Cultural Politics and Market Ethics'. In Ethical Life in South Asia, edited by Anand Pandian and Daud Ali, 83-Ioo. Bloomington: Indiana University Press.

Birla, Ritu. 20Ir. 'Law as Economy: Convention, Corporation, Currency'. UC Irvine Law Review I: IOI5.

Birla, Ritu. 2015. 'Jurisprudence of Emergence: Neo-Liberalism and the Public as Market in India'. South Asia: Journal of South Asian Studies $3^{8}$ (3): 466-80. https://doi.org/Io.108o/ 00856401.2015.1049685 (accessed 24 September 2019).

Bourdieu, Pierre. 1977a. 'Cultural Reproduction and Social Reproduction'. In Power and Ideology in Education, edited by Jerome Karabel and A. H. Halsey, 487-5II. New York: Oxford University Press.

Bourdieu, Pierre. 1977b. Outline of a Theory of Practice. New York: Cambridge University Press.

Bourdieu, Pierre. 200o. 'Making the Economic Habitus: Algerian Workers Revisited'. Ethnography I (I): I7-4I. https://doi.org/Io.II77/I466I380022230624 (accessed 24 September 2019).

Bourdieu, Pierre. 2005. The Social Structures of the Economy. Cambridge: Polity.

Buswala, Bhawani. 2016. 'The Bazaar and the Butchers: The Social Life of an Untouchable Work in North India'. PhD Thesis, Rhode Island: Brown University.

Callon, Michel (ed.). I998. The Laws of the Markets. Oxford: Blackwell Publishers.

Carswell, Grace, and Geert de Neve. 20I4. 'T-Shirts and Tumblers'. Contributions to Indian Sociology 48 (I): 103-31.

Carswell, Grace, Geert de Neve, and Judith Heyer. 2018. 'Caste Discrimination in Contemporary Tamil Nadu: Evidence from the Tiruppur Textile Region'. In Contested Hierarchies, Persisting Influence Caste and Power in Twenty-First Century India, edited by Surinder Jodhka and James Manor, I72-206. Hyderabad: Orient Blackswan.

Castellino, Joshua. 2017. 'How Effective Has CERD Been at Protecting Minorities?'. In Fiffy Years of the International Convention on the Elimination of All Forms of Racial Discrimination: A Living Instrument, edited by David Keane and Annapuma Waughray, 227-45. Manchester: Manchester University Press. 
Chari, Sharad. 2004. Fraternal Capital: Peasant-Workers, Self-Made Men, and Globalization in Provincial India. Stanford: Stanford University Press.

Coffey, Diane, and Dean Spears. 2017. Where India Goes: Abandoned Toilets, Stunted Development and the Costs of Caste. Delhi: Harper Collins India.

Coffey, Diane, Aashish Gupta, Payal Hathi, Dean Spears, Nikhil Srivastav, and Sangita Vyas. 2017. 'Understanding Open Defecation in Rural India: Untouchability, Pollution, and Latrine Pits'. Economic and Political Weekly $5^{2}$ (I): 59-66.

Curtis, Jennifer, and Jonathan Spencer. 2012. 'Anthropology and the Political'. In The SAGE Handbook of Social Anthropology, edited by Richard Fardon et al., i68-82. London: SAGE Publications.

Damodaran, H. 2008. India's New Capitalists: Caste, Business, and Industry in a Modern Nation. Basingstoke \& New York: Palgrave.

Das, Maitreyi. 2013. 'Exclusion and Discrimination in the Labor Market'. ID 218170I. World Development Report 2013 Background Paper. Rochester, NY: The World Bank.

Das, Maitreyi Bordia. 2010. 'Minority Status and Labor Market Outcomes: Does India Have Minority Enclaves?'. In Blocked by Caste: Economic Discrimination in Modern India, edited by Sukhadeo Thorat and Katherine Newman, 328-53. New Delhi: Oxford University Press.

David, Kenneth. 1977. 'Hierarchy and Equivalence in Jaffna, North Sri Lanka: Normative Codes as Mediator.' In The New Wind: Changing Identities in South Asia, edited by Kenneth David, 179-226. The Hague and Paris: Mouton.

Deshpande, A. 2017. The Grammar of Caste: Economic Discrimination in Contemporary India. Paperback edition. Oxford, New York: Oxford University Press.

Deshpande, A., and Katherine Newman. 2007. 'Where the Path Leads: The Role of Caste in Post-University Employment Expectations'. Economic and Political Weekly 42 (4I): 4133-40.

Deshpande, Ashwini. 2018. 'Caste, Class and Social Mobility: The Critical Role of High School Years'. mimeo.

Deshpande, Ashwini, and Rajesh Ramachandran. 2017. 'Dominant or Backward? Political Economy of Demand for Quotas by Jats, Patels, and Marathas'. Economic and Political Weekly 52 (19): 8I-92.

Deshpande, Satish. 2013. 'Caste and Castelessness: Towards a Biography of the "General Category". Economic and Political Weekly 48 (I5): 32-39.

Dirks, Nicholas B. 200I. Castes of Mind: Colonialism and the Making of Modern India. Princeton: Princeton University Press.

Dumont, Louis. 1977. From Mandeville to Marx: The Genesis and Triumph of Economic Ideology. Chicago: University of Chicago Press.

Dumont, Louis. I980. Homo Hierarchicus: The Caste System and Its Implications. Chicago: University of Chicago Press.

Engineer, Irfan. 2015. 'Modi Sarkar's First Birthday'. INSAF Bulletin I58 (June). http://www. insafbulletin.net/archives/2934\#more-2934 (accessed 24 September 2019).

Fuller, Christopher. 1989. 'Misconceiving the Grain Heap: A Critique of the Concept of the "Indian Jajmani System"'. In Money and the Morality of Exchange, edited by Jonathan Parry and Maurice Bloch, 33-63. Cambridge: Cambridge University Press.

Fuller, Christopher. 20II. 'Caste, Race, and Hierarchy in the American South'. Journal of the Royal Anthropological Institute I7 (3): 604-2I.

Fuller, Christopher, and Haripriya Narasimhan. 20I4. Tamil Brahmans: The Making of a Middle-Class Caste. Chicago: University of Chicago Press.

Galanter, Marc. 1984. Competing Inequalities: Law and the Backward Classes in India. Oxford: Oxford University Press. 
Gill, Kaveri. 2012. Of Poverty and Plastic: Scavenging and Scrap Trading Entrepreneurs in India's Urban Informal Economy. New Delhi: Oxford University Press.

Goel, Deepti, and Ashwini Deshpande. 2016. 'Identity, Perceptions and Institutions: Caste Differences in Earnings from Self-Employment in India'. Working Paper 259. Delhi: Centre for Development Economics, Delhi School of Economics.

Good, Anthony. 1982. 'The Actor and the Act: Categories of Prestation in South India'. Man I7 (I): 23-4I.

Granovetter, Mark. 1985. 'Economic Action and Social Structure: The Problem of Embeddedness'. American fournal of Sociology 9I (3): 48 $\mathrm{I}^{-} 5^{\mathrm{IO}}$.

Gupta, Dipankar. 2005. 'Caste and Politics: Identity over System'. Annual Review of Anthropology 34 (I): 409-27.

Habib, Irfan. 1982. 'Northern India under the Sultanate: Agrarian Economy; Agrarian Relations and Land Revenue: North India; Monetary System and Prices'. In Cambridge Economic History of India, Vol. I, edited by Tapan Raychaudhuri and Irfan Habib, Chs. 3, pts 2; 9, I; I2. Cambridge: Cambridge University Press.

Habib, Irfan. 2002. Essays in Indian History: Towards a Marxist Perception. London: Anthem Press.

Harris, Cheryl I. I993. 'Whiteness as Property'. Harvard Law Review Io6 (8): I707-9I. https://doi. org/10.2307/I341787 (accessed 24 September 2019).

Harriss, John. 2003. "Widening the Radius of Trust": Ethnographic Explorations of Trust and Indian Business'. Fournal of the Royal Anthropological Institute 9 (4): 755-73.

Harriss-White, Barbara. 2003. India Working: Essays on Society and Economy. Cambridge: Cambridge University Press.

Harriss-White, Barbara. 2017. 'Matter in Motion: Work and Livelihoods in India's Economy of Waste'. In Critical Perspectives on Work and Employment in Globalizing India, edited by Ernesto Noronha and Premilla D'Cruz, 95-III. Singapore: Springer.

Harriss-White, Barbara. n.d. Dalits and Adivasis in India's Business Economy (Three Essays Collective, 2013) Podcast. New Books in South Asian Studies. https://itunes.apple.com/gb/podcast/ barbara-harriss-white-dalits-adivasis-in-indias-business/id427197319? $\mathrm{i}={ }_{1000364255812 \& m t=2}($ accessed 24 September 2019).

Harriss-White, Barbara, and Aseem Prakash. 2015. 'Social Discrimination and Economic Citizenship'. In The Indian Economy in Transition: Essays in Honour of CT Kurien, edited by S. Janakarajan, L. Venkatachalam, and R. Maria Saleth, 294-326. New Delhi: Sage Publications.

Harriss-White, Barbara, and Kaushal Vidyarthee. 2010. 'Stigma and Regions of Accumulation: Mapping Dalit and Adivasi Capital in the 199os'. In The Comparative Political Economy of Development: Africa and South Asia, edited by Barbara Harriss-White and Judith Heyer, 31749. Abingdon \& New York: Routledge.

Harriss-White, Barbara, Kaushal Vidyarthee, and Anita Dixit. 20I4. 'Regions of Dalit and Adivasi Discrimination in India's Business Economy'. In Dalits and Adivasis in India's Business Economy: Three Essays and an Atlas, edited by B. Harriss-White et al. Gurgaon: Three Essays Collective.

Hastrup, Kirsten. 2006. 'Closing Ranks: Fundamentals in History, Politics and Anthropology'. The Australian Fournal of Anthropology i7 (2): 147-60.

Himanshu, Peter Lanjouw, Rinku Murgai, and Nicholas Stern. 2013. 'Nonfarm Diversification, Poverty, Economic Mobility, and Income Inequality: A Case Study in Village India'. Agricultural Economics 44 (4-5): 46I-73.

Hirschman, Albert O. 1982. 'Rival Interpretations of Market Society: Civilizing, Destructive, or Feeble?'. Fournal of Economic Literature 20 (4): $1463-84$. 
Hoff, Karla. 2016. 'Caste System'. Policy Research Working Paper Series 7929. Washington, DC: The World Bank. https://ideas.repec.org/p/wbk/wbrwps/7929.html (accessed 24 September 2019).

Hoff, Karla, and Priyanka Pandey. 2006. 'Discrimination, Social Identity, and Durable Inequalities'. American Economic Review 96 (2): 206-II.

Iversen, Vegard, and P. S. Raghavendra. 2006. 'What the Signboard Hides: Food, Caste and Employability in Small South Indian Eating Places'. Contributions to Indian Sociology 4o (3): $3 \mathrm{II}-4 \mathrm{I}$.

Iyer, L., Tarun Khanna, and Ashutosh Varshney. 2013. 'Caste and Entrepreneurship in India'. Economic and Political Weekly $4^{8}$ (6): 52-6o.

Jadhav, Sushrut, David Mosse, and Ned Dostaler. 20r6. 'Minds of Caste-Discrimination and Its Affects'. Anthropology Today 32 (I): I-2.

Jaffrelot, Christophe. 2006. 'The Impact of Affirmative Action in India: More Political than Socioeconomic'. India Review 5 (2): 173-89.

Jaffrelot, Christophe. 2015. 'What "Gujarat Model"? — Growth without Development-and with Socio-Political Polarisation'. South Asia: Journal of South Asian Studies $3^{8}$ (4): 820-38.

Jayal, Niraja Gopal. 2015. 'Affirmative Action in India: Before and after the Neo-Liberal Turn'. Cultural Dynamics 27 (I): II7-33.

Jeffrey, Craig, Patricia Jeffery, and Roger Jeffery. 2008. Degrees Without Freedom? Education, Masculinities, and Unemployment in North India. Stanford: Stanford University Press.

Jodhka, Surinder. 2010. 'Dalits in Business: Self-Employed Scheduled Castes in North-West India'. Economic and Political Weekly 45 (II): $4 \mathrm{I}^{\mathrm{I}} 48$.

Jodhka, Surinder, and James Manor. 2018. 'Introduction'. In Contested Hierarchies, Persisting Influence: Caste and Power in Twenty-First Century India, edited by Surinder S. Jodhka and James Manor, I-38. Hyderabad: Orient Black Swan.

Kalpagam, U. 2000. 'Colonial Governmentality and the "Economy"'. Economy and Society 29 (3): $4{ }^{18-38 .}$

Kapila, Shruti. 2015. 'The Majority of Democracy'. Social Text Online-Periscope, Indian Politics Under Modi, 27 February. https://socialtextjournal.org/periscope_article/the-majority-ofdemocracy/ (accessed 24 September 2019).

Kapila, Shruti. 2019. 'Ambedkar's Agonism'. Comparative Studies of South Asia, Africa and the Middle East 39 (I): $184-95$.

Kapila, Shruti. Forthcoming. Violent Fraternity: Global Political Thought in the Indian Age. Book manuscript under review.

Kapur, Devesh, Chandra Bhan Prasad, Lant Pritchett, and D. Shyam Babu. 2010. 'Rethinking Inequality: Dalits in Uttar Pradesh in the Market Reform Era'. Economic and Political Weekly 45 (35): $39-49$.

Keane, Webb. 2008. 'Market, Materiality and Moral Metalanguage'. Anthropological Theory 8 (I): 27-42. https://doi.org/Io.1177/I463499607087493 (accessed 24 September 2019).

Krishna, Anirudh. 2017. The Broken Ladder: The Paradox and Potential of India's One-Billion. New York: Cambridge University Press.

Krishna, Anirudh. 2018a. 'Alternatives to Caste-Based Channels of Influence'. In Contested Hierachies, Persisting Influence: Caste and Power in Twenty-First Century India, edited by Surinder Jodhka and James Manor, 87-Io8. Hyderabad: Orient Blackswan.

Krishna, Anirudh. 2018b. 'Rural-Urban Inequality and Poverty'. In Inequality in Economics and Sociology: New Perspectives, edited by Gilberto Antonelli and Boike Rehbein, I62-73. London \& New York: Routledge. 
Krishnan, Rajan. 2012. 'Caste and Religion in the Age of the Nation-State: Certain Polemical Blinders and Dalit Situations'. Conference Paper, Caste Out of Development, Chennai, December 20II. https://s3-eu-west-I.amazonaws.com/esrc-files/outputs/J82yJjiwSECQUz HETZM6iQ/he2lQhWE6U2-EuU3JJZDxg.pdf (accessed 5 October 2019).

Lanjouw, Peter, and Vijayendra Rao. 20II. 'Revisiting Between-Group Inequality Measurement: An Application to the Dynamics of Caste Inequality in Two Indian Villages'. World Development, Ethnicity and Ethnic Strife 39 (2): I74-87.

Lehne, Jonathan, Jacob N. Shapiro, and Oliver Vanden Eynde. 2018. 'Building Connections: Political Corruption and Road Construction in India'. Fournal of Development Economics I3I (March): 62-78.

Lindner, Evelin. 2010. Gender, Humiliation, and Global Security: Dignifying Relationships from Love, Sex, and Parenthood to World Affairs. Denver \& Oxford: Praeger.

Luke, Nancy, and Kaivan Munshi. 201r. 'Women as Agents of Change: Female Income and Mobility in India'. Fournal of Development Economics 94 (I): I-I7.

MacKenzie, Donald A., Fabian Muniesa, and Lucia Siu. 2007. Do Economists Make Markets? On the Performativity of Economics. Princeton, NJ: Princeton University Press.

Mair, Michael, Christian Greiffenhagen, and W. W. Sharrock. 2016. 'Statistical Practice: Putting Society on Display'. Theory, Culture \& Society 33 (3): 5 I-77.

Mehta, Uday. 2010. 'The Social Question and the Absolutism of Politics'. Seminar 615.

Miller, Daniel. 2002. 'Turning Callon the Right Way Up'. Economy and Society 3I (2): 218-33.

Mines, Diane P. 2005. Fierce Gods: Inequality, Ritual, and the Politics of Dignity in a South Indian Village. Bloomington: Indiana University Press.

Mitchell, Timothy. 1998. 'Fixing the Economy'. Cultural Studies I2 (I): 82-IOI.

Mitchell, Timothy. 2008. 'Rethinking Economy'. Geoforum 39 (3): III6-2I.

Mohr, John W., and Harrison C. White. 2008. 'How to Model an Institution'. Theory and Society 37 (5): $485^{-5} 5^{12 .}$

Mosse, David. 2003. The Rule of Water: Statecraft, Ecology and Collective Action in South India. New Delhi: Oxford University Press.

Mosse, David. 20го. 'A Relational Approach to Durable Poverty, Inequality and Power'. The Fournal of Development Studies 46 (7): $1156-78$.

Mosse, David. 2012. The Saint in the Banyan Tree: Christianity and Caste Society in India. Berkeley: University of California Press.

Mosse, David. 2015. 'Class, Caste and the Reproduction of Privilege'. Anthropology of This Century I4. http://aotcpress.com/articles/class-caste-reproduction-privilege/ (accessed 24 September 20I9).

Mosse, David. 2017. 'Narratives, Networks and NGOs: Dalit Rights and Development in South India. OP Jindal Lecture 2017'. Presented at the OP Jindal Lecture 2017, Brown University, 3 November. http://watson.brown.edu/events/2017/op-jindal-lecture-david-mosse-narrativesnetworks-and-ngos-dalit-rights-and-development (accessed 24 September 2019).

Mosse, David. 2018a. 'Caste and Development: Contemporary Perspectives on a Structure of Discrimination and Advantage'. World Development i Io: 422-36.

Mosse, David. 2018b. 'Caste, Religion and Nation: The Relationship between Christianity and Caste Society in India and Its Misconstrual'. In Contesting Hierarchies, Persisting Influence: Caste and Power in Twenty-First Century India, edited by Surinder Jodhka and James Manor, 26I-9o. Hyderabad: Orient Blackswan.

Mosse, David. 2020. 'Outside Caste? The Enclosure of Caste and Claims to Castelessness in India and the UK'. Comparative Studies in Society and History 62 (I), in press.

Munshi, Kaivan. 2011. 'Strength in Numbers: Networks as a Solution to Occupational Traps'. Review of Economic Studies 78 (3): Io69-IIOI. 
Munshi, Kaivan. 2014. 'Community Networks and the Process of Development'. The Fournal of Economic Perspectives 28 (4): 49-76.

Munshi, Kaivan. 2016a. 'Caste and the Indian Economy'. Cambridge. http://www.histecon. magd.cam.ac.uk/km/Munshi_JELi.pdf (accessed 24 September 2019).

Munshi, Kaivan. 2016b. 'Caste Networks in the Modern Indian Economy'. In Development in India: Micro and Macro Perspectives, edited by S. Mahindra Dev and P. Babu, 13-37. New Delhi: Springer India.

Munshi, Kaivan, and Mark Rosenzweig. 2006. 'Traditional Institutions Meet the Modern World: Caste, Gender, and Schooling Choice in a Globalizing Economy'. American Economic Review 96 (4): 1225-52.

Munshi, Kaivan. 2009. 'Why Is Mobility in India so Low? Social Insurance, Inequality, and Growth'. Working Paper I4850. National Bureau of Economic Research. http://www. nber.org/papers/wi4850 (accessed 24 September 2019).

Natrajan, Balmurli. 20I. The Culturalization of Caste in India: Identity and Inequality in a Multicultural Age. London: Routledge.

Natrajan, Balmurli. 2012. 'From Jati to Samaj'. Seminar 633 (May): 54-57.

Natrajan, Balmurli. 2018. 'Cultural Identity and Beef Festivals: Toward a "Multiculturalism against Caste"”. Contemporary South Asia 26 (3): 287-304.

NCSC. 20I6. National Commission for Scheduled Castes -Handbook 20I6. New Delhi: National Commission for Scheduled Castes. www.ncsc.nic.in (accessed 24 September 2019).

Pandey, Gyanendra. 2013. A History of Prejudice: Race, Caste, and Difference in India and the United States. Cambridge: Cambridge University Press.

Pandian, M. S. S. 2002. 'One Step Outside Modernity: Caste, Identity Politics and Public Sphere'. Economic and Political Weekly 37 (18): 1735-4I.

Pathania, Gaurav J., and William G. Tierney. 2018. 'An Ethnography of Caste and Class at an Indian University: Creating Capital'. Tertiary Education and Management 24 (3): 22I-3I

Polanyi, Karl. 1957. The Great Transformation: The Political and Economic Origins of Our Time. Boston: Beacon Press.

Prakash, Aseem. 2015. Dalit Capital: State, Markets and Civil Society in Urban India. New Delhi: Routledge India.

Prasad, Chandra Bhan. 2008. 'Markets and Manu: Economic Reforms and Its Impact on Caste in India'. CASI Working Paper Series, Center for the Advanced Study of India, Number o8-oI: $\mathrm{I}^{-} 33$.

Rao, Anupama. 2009. The Caste Question: Dalits and the Politics of Modern India. Berkeley: University of California Press.

Rawat, Ramnarayan, and K. Satyanarayana. 2016. 'Introduction. Dalit Studies: New Perspectives on Indian History and Society'. In Dalit Studies, I-30. Durham \& London: Duke University Press.

Roberts, Nathaniel. 2016. To Be Cared For: The Power of Conversion and Foreignness of Belonging in an Indian Slum. Berkeley: University of California Press.

Roberts, Nathaniel. 2017. 'Race and Caste: From Hierarchies of Value to Analytics of Power'. Seminar paper presented at the London School of Economics, Department of Anthropology Seminar, 8 December.

Rosen, George. 1978. 'From Mandeville to Marx: The Genesis and Triumph of Economic Ideology. Louis Dumont'. Economic Development and Cultural Change 27 (I): 206-I4.

Shah, Alpa, Jens Lerche, Richard Axelby, Dalel Benbabaali, Brendan Donegan, Jayaseelan Raj, and Vikramaditya Thakur. 2018. Ground Down by Growth: Tribe, Caste, Class and Inequality in 2Ist Century India. London: Pluto Press. 
Shanmugavelan, Murali. 2018. 'Everyday Communicative Practices of Arunthathiyars: The Contribution of Communication Studies to the Analysis of Caste Exclusion and Subordination of a Dalit Community in Tamil Nadu, India'. Draft PhD Thesis, SOAS University of London.

Sharma, Smriti. 2015. 'Caste-Based Crimes and Economic Status: Evidence from India'. Fournal of Comparative Economics 43 (I): 204-26.

Siddique, Zahra. 2011. 'Evidence on Caste Based Discrimination'. Labour Economics, Labour Markets in Developing Countries I8: $\mathrm{S}_{4} 46-59$.

Singh, Bhasha. 2014. Unseen: The Truth about India's Manual Scavengers. New Delhi: Penguin Books India.

Singh, Gayatri, and Trina Vithayathil. 2012. 'Residential Segregation in Indian Cities Spaces of Discrimination'. Economic and Political Weekly 47 (37): 6o-66.

Slater, Don. 2002. 'From Calculation to Alienation: Disentangling Economic Abstractions'. Economy and Society 3I (2): 234-49.

Still, Clarinda. 2015. 'Comparing Race and Caste'. Anthropology of This Century I2 (January). http://aotcpress.com/articles/comparing-race-caste/ (accessed 24 September 2019).

Strathern, Marilyn. 1996. 'Cutting the Network'. The Journal of the Royal Anthropological Institute 2 (3): $5^{\mathrm{I}} 7^{-}-35$.

Subramanian, Ajantha. 2015. 'Making Merit: The Indian Institutes of Technology and the Social Life of Caste'. Comparative Studies in Society and History 57 (2): 291-322.

Swedberg, Richard. 2011. 'The Economic Sociologies of Pierre Bourdieu'. Cultural Sociology 5 (I): $67-82$.

Tam, Stephanie. 2013. 'Sewerage's Reproduction of Caste'. Radical History Review ir6 (Spring): 5-30.

Tharamangalam, Joseph. 20r6. 'Moditva in India: A Threat to Inclusive Growth and Democracy'. Canadian Journal of Development Studies/Rerue Canadienne d'études Du Développement 37 (3): $29^{8}-3 \mathbf{5}$.

Thorat, Sukhadeo, and Paul Attewell. 2007. 'The Legacy of Social Exclusion'. Economic and Political Weekly 42 (4I): 4I $\mathrm{I}^{\mathrm{I}-45}$.

Thorat, Sukhadeo, Anuradha Banerjee, Vinod Mishra, and Firdaus Rizvi. 2015. 'Urban Rental Housing Market: Caste and Religion Matters in Access'. Economic and Political Weekly 50 (56 \& 57): $47-53$.

Thorat, Sukhadeo, Debolia Kundu, and Nidhi Sadana. 2010. 'Caste and Ownership of Private Enterprise: Consequences of Denial of Property Rights'. In Blocked by Caste: Economic Discrimination in Modern India, edited by Sukhadeo Thorat and Katherine Newman, 31 I-27. New Delhi: Oxford University Press.

Thorat, Sukhadeo, Ajaya K. Naik, and Nitin Tagade. 2016. 'Prejudice against Reservation Policies: How and Why?'. Economic and Political Weekly 5I (8): 6I-69.

Tilly, Charles. 1998. Durable Inequality. Berkeley: University of California Press.

Tilly, Charles. 200I. 'Relational Origins of Inequality'. Anthropological Theory I (3): 355-72.

Tilly, Charles. 2007. 'Poverty and the Politics of Exclusion'. In Moving Out of Poverty; Cross-Disciplinary Perspectives on Mobility, edited by Deepa Narayan and Patti Petesch, 45-76. Washington, DC: The World Bank.

Upadhya, Carol. 2007. 'Employment, Exclusion and "Merit" in the Indian IT Industry'. Economic and Political Weekly 42 (20): 1863-68.

Vidyarthee, Kaushal. 20I6. 'The Incorporation of Dalits into India's Business Economy \& Its Implications for Social and Economic Policies'. DPhil Thesis, University of Oxford.

Viswanath, Rupa. 20I4a. 'Rethinking Caste and Class: "Labour", the "Depressed Classes", and the Politics of Distinctions, Madras I918-I924'. International Review of Social History 59 (I): I-37. 
Viswanath, Rupa. 2014b. The Pariah Problem: Caste, Religion, and the Social in Modern India. New York: Columbia University Press.

Vithayathil, Trina. 2018. 'Counting Caste: Censuses, Politics, and Castelessness in India'. Politics \& Society 46 (4): $455^{-84}$.

Waughray, Annapurna. 2010. 'Caste Discrimination and Minority Rights: The Case of India's Dalits'. International Journal on Minority and Group Rights I7: 327-53.

Witsoe, Jeffrey. 2013. Democracy against Development: Lower-Caste Politics and Political Modernity in Postcolonial India. Chicago: University of Chicago Press.

Witsoe, Jeffrey. 2018. 'Caste Networks and Regional Political Economy'. In Contested Hierarchies, Persisting Influence: Caste and Power in Twenty-First Century India, edited by Surinder Jodhka and James Manor, 39-59. Hyderabad: Orient Blackswan.

World Bank, The. 2011. Poverty and Social Exclusion in India. Washington, DC: World Bank Publications.

Wrench, John. 2016. 'Dubious Types and Boundary Disputes: Contested Understandings of Concepts of Discrimination'. Robert Schuman Centre for Advanced Studies Working Paper RSCAS 2016/39. San Domenico di Fiesole, Italy: European University Institute. https://pdfs.semanticscholar.org/2da3/rea58di28ı85b65breer5fofo5a49dd4red4.pdf?_ga =2. 223937950.440129759.1571213858-I73594625.1566937534 (accessed 21 October 2019). 